Florida International University FIU Digital Commons

\title{
Land use of riparian zones in two communities in the Palcazu basin, central Andean Amazon, Peru
}

Rosa E. Cossio-Solano

Florida International University

DOI: $10.25148 /$ etd.FI14061528

Follow this and additional works at: https://digitalcommons.fiu.edu/etd

Part of the Environmental Sciences Commons

\section{Recommended Citation}

Cossio-Solano, Rosa E., "Land use of riparian zones in two communities in the Palcazu basin, central Andean Amazon, Peru" (2001). FIU Electronic Theses and Dissertations. 2645.

https://digitalcommons.fiu.edu/etd/2645 


\title{
FLORIDA INTERNATIONAL UNIVERSITY
}

\author{
Miami, Florida
}

LAND USE OF RIPARIAN ZONES IN TWO COMMUNITIES IN THE PALCAZU

BASIN, CENTRAL ANDEAN AMAZON, PERU

A thesis submitted in partial fulfillment of the

requirements for the degree of

MASTER OF SCIENCE

in

ENVIRONMENTAL STUDIES

by

Rosa E. Cossío-Solano

2001 
This thesis, written by Rosa E. Cossío-Solano, and entitled Land Use of Riparian Zones in Two Communities in the Palcazu Basin, Central Andean Amazon, Peru, having been approved in respect to style and intellectual content, is referred to you for judgment.

We have read this thesis and recommend that it be approved.

Dr. David Bray

Dr. Bradley Bennett

Dr. Walter Peacock

Dr. Michael McClain, Major Professor

Date of Defense: November 26, 2001

The thesis of Rosa E. Cossío-Solano is approved.

Dean Arthur W. Herriott College of Arts and Sciences

Dean Douglas Wartzok University Graduate School

Florida International University, 2001 


\section{DEDICATION}

I dedicate this thesis to my parents, grandfather, sister, and brothers who always were with me even at the distance. To the memory of my grandmother, who was always a model of perseverance to follow. And I also want to dedicate this thesis to my friends, my older friends and the new ones, who were a big support to me during these 2 years. Special mention to my best friend whose advice and help were great, mainly his emotional support. 


\section{ACKNOWLEDGMENTS}

I wish to thank Inter American Foundation for its valuable economic funding, which made my master studies possible. Funding for the field portion of my study came from the Inter American Institute for Global Change Research (IAI). To the people of my studied communities: Laguna-Raya and Santa María, who helped to me answering the questionnaires, and guiding to me in the field. To the members of my committee for their support and patience. Dr. Walter Peacock was particularly helpful in guiding me in the statistical part. Dr. Bradley Bennett helped to me with scientific nomenclature. My friend Dr. David Bray gave to me support from the beginning of my master studies, and was very helpful with his suggestions and advice in the elaboration of my thesis.

Finally, I would like to thank my major professor and friend Dr. Michael McClain, and his family, who from the beginning gave to me their support and their friendship. 
LAND USE OF RIPARIAN ZONES IN TWO COMMUNITIES IN THE PALCAZU

BASIN, CENTRAL ANDEAN AMAZON, PERU

by

\author{
Rosa E. Cossio-Solano
}

Florida International University, 2001

Miami, Florida

Professor Michael McClain, Major Professor

The purpose of this study was to compare outcomes in forms of riparian zone land use between a native and a colonist community of the Palcazu basin in Peru.

Data were gathered through a survey of 79 settler households and an ethnographic study.

The results showed that riparian zones are highly valued for the conservation of fertile lowland soils by both communities. Statistical tests showed that riparian land use practices (including non-riparian land use) in both communities are similar; only significant differences were found in the percentage of protection fringe forested, in the area of riparian zone under use and in the importance of riparian zones for the householders.

Contextual circumstances in both communities are similar and markets are distant. My research also suggests that there is nothing inherent in the culture of either Yanesha peoples or colonists that leads them to open more or less agricultural land. 
II. CONCEPTUAL LITERATURE REVIEW ...........................................6 6

Riparian zones in the Amazon Basin ........................................................ 6

The legal framework for riparian zone in the Peruvian Amazon ........................ 11

The Palcazu basin ...................................................................................... 12

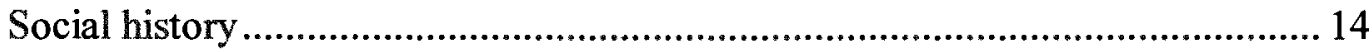

Occupation of the Pachitea basin................................................................ 14

Communal and colonist land tenure .......................................................... 16

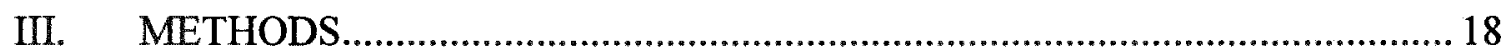

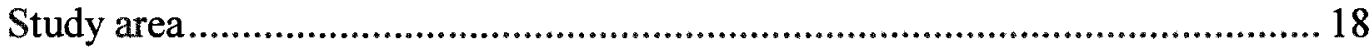

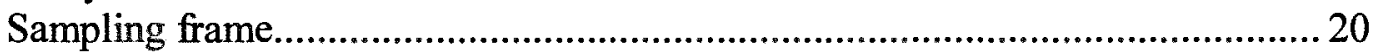

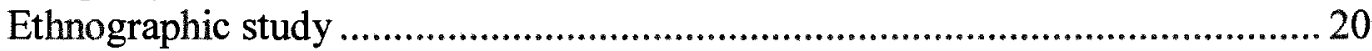

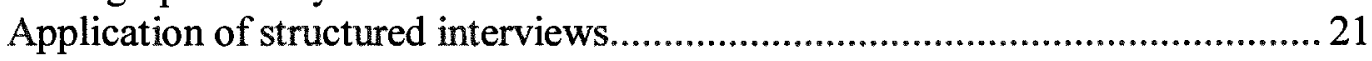

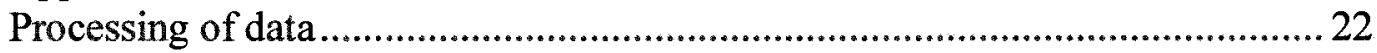

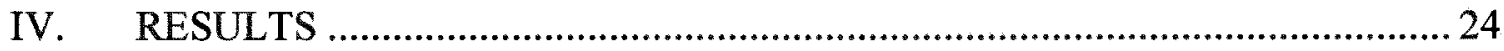

RESULTS FROM ETHNOGRAPHIC STUDY ……...................................... 24

Laguna-Raya sector ................................................................................ 24

The formation of the community ...................................................................2 27

General characteristics of the community ...................................................... 27

Land common property institutions and land tenure ............................................ 29

Economic activities........................................................................................ 30

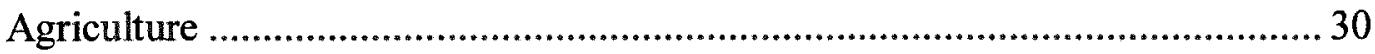

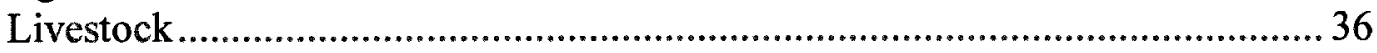

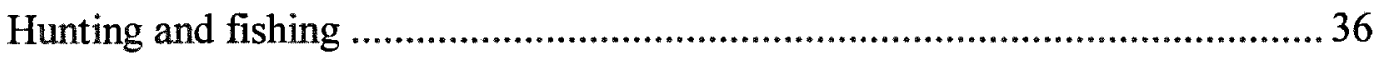

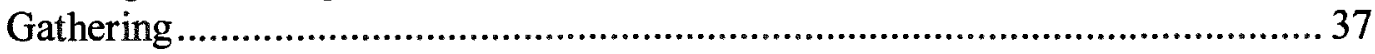

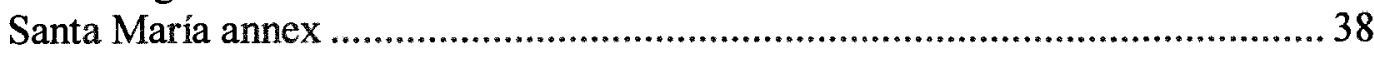

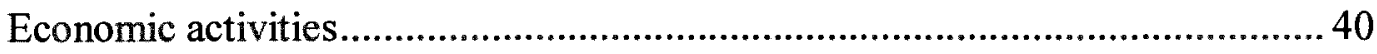

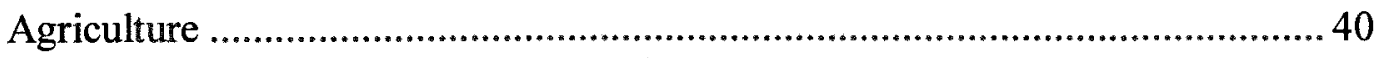

Livestock, hunting, fishing and gathering ...................................................... 41

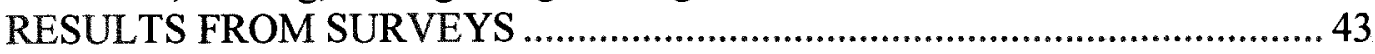

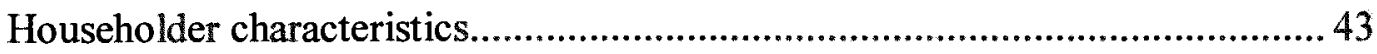

Land common property institutions and land tenure ................................... 46

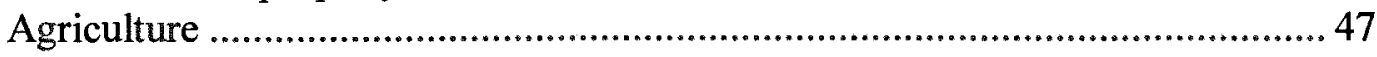

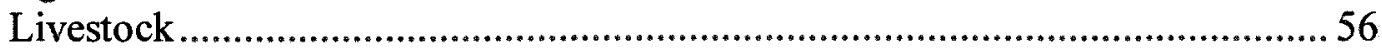

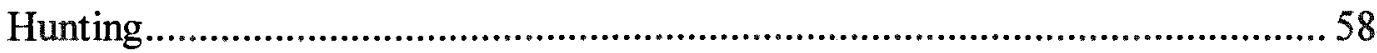

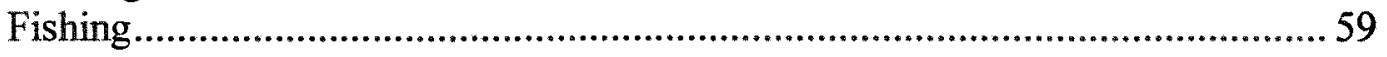




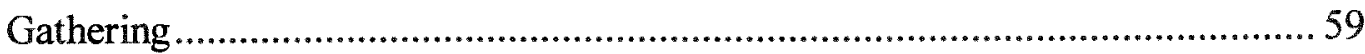

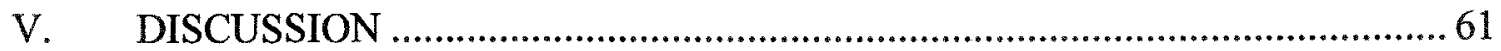

Householder characteristics........................................................................6 61

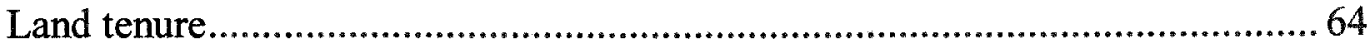

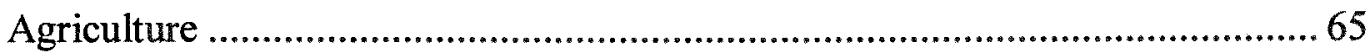

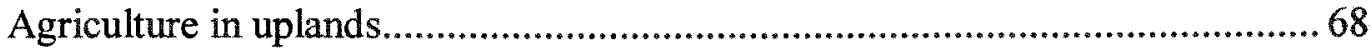

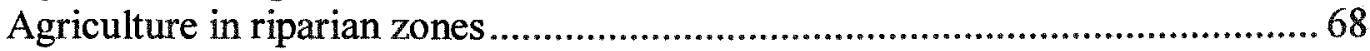

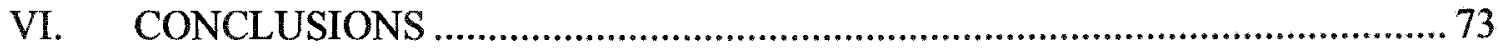

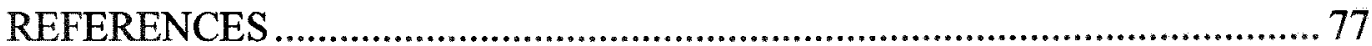

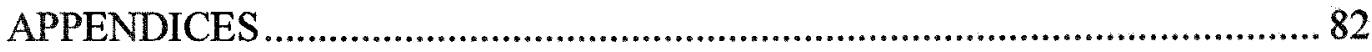




\section{LIST OF TABLES}

TABLE

PAGE

1. Principal crops in riparian zones in Laguna-Raya .......................................... 34

2. Plants species in riparian zones in Laguna-Raya.......................................... 35

3. Common medicinal plants and their uses in Laguna-Raya................................. 37

4. Crops in riparian zones in Santa María............................................................. 41

5. Common medicinal plants and their uses in Santa María.................................. 42

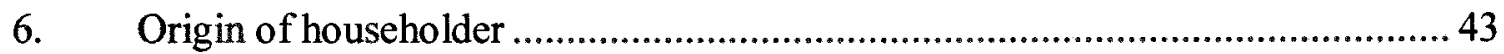

7. Mean values-Householder characteristics...................................................... 44

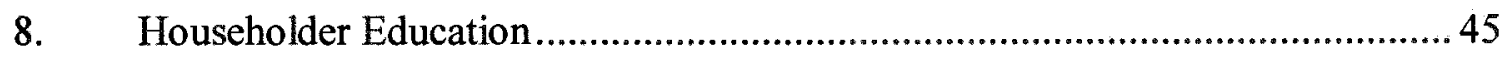

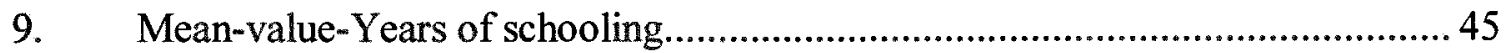

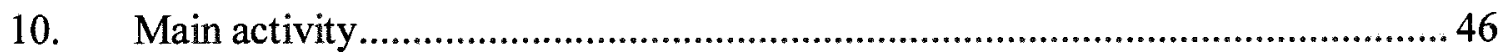

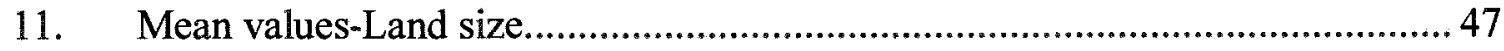

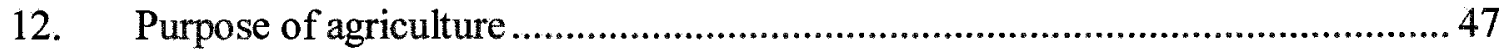

13. Mean values-General agriculture characteristics.............................................48

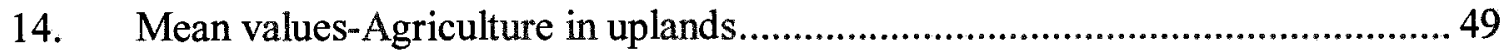

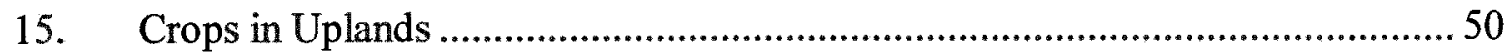

16. Number of people with access to riparian zones (RZs) ..................................5 51

17. Situation of riparian zones at arrival to the community ....................................5 51

18. Treatment of riparian vegetation at arrival to the community.............................51

19. Mean values and percentages-Riparian zones characteristics.........................552

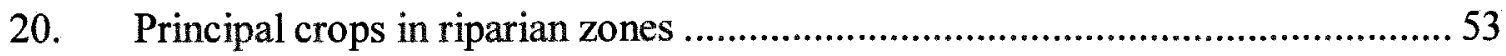

21. Principal reason to plant some crops in Riparian zones.................................... 54 


\section{INTRODUCTION}

Riparian environments, the ecotone between terrestrial and aquatic ecosystems, provide services on which the ecological integrity and health of rivers and uplands depend. These services include protection of surface water quality, habitats, and corridors for the migration of plant and animals species. Humans have historically utilized floodplains because of access to transportation, water and fertile soils. However because of unplanned use of these areas, more than $80 \%$ of North American and European riparian zones have disappeared in the last 200 years (Naiman and Décamps, 1993).

The extent of degradation of riparian zones in the Peruvian Amazon is not well documented. However while North America and Europe have seen a severe loss of the ecosystem services provided by intact riparian forest, riparian zones and the associated services remain more or less intact in the Amazon basin.

However, even in the Peruvian Amazon there are many factors that cause pressure on land use in both riparian zones and uplands. Principal among then is immigration from the highlands (Sierra) to the lowland rainforest (Selva). Many people immigrate to the Selva with the hope of finding land. These people bring a culture and agricultural practices that are incompatible with the reality of the Selva. Low income, few sources of non-agrarian employment, and low level of education are factors that increase pressure on land.

My study was conducted within the context of a larger investigation (Andean Amazon Rivers Analysis and Management Project) which is focused on the consequences of land use change on ecological functions in riparian forests and adjoining riverine ecosystems. It was carried out in two communities in the Palcazu basin: Laguna- 
Raya, a sector in the Loma Linda-Laguna Native Community, a predominantly indigenous Yanesha community; and Santa María, a predominantly colonist town, composed by people who have migrated from other parts of the country.

A basic conclusion of this research is that there is not a significant difference between indigenous and colonist households in these two communities with regard to riparian zone land use. In the Palcazu basin, where my research took place indigenous peoples in Laguna-Raya appear to have utilized the river's edge from a very early period. There are some reports that indigenous peoples in this area did not traditionally use riparian zones for agriculture, preffering upland areas. However in Laguna-Raya these converted Adventist Yanesha do appear to have shown a preference from the beginning. Recent colonists also showed a strong preference from the beginning for establishing agricultural plots in riparian zones, progressively transforming riparian forests into agricultural fields.

The major point that I adress in this study is the comparison in outcomes in forms of riparian zone land use between indigenous and colonist in the Palcazu basin. I examine how farmers in riparian communities make or do not make particular use of riparian zones for production and what are the behavioral patterns and community rules that govern land use in general and riparian land use in particular.

This research seeks to understand the forces that may lead to riparian degradation within communities of the central Peruvian Amazon and to contribute to our understanding of how degradation can be avoided. 
As will be discussed later, one of my two study communities is an indigenous community where the territory is administered as common property. In 1968, Garret Hardin (in Ostrom et al, 1999) argued that "users of commons are caught in an inevitable process that leads to the destruction of the resources on which they depend". However examples presented by Ostrom et al show that common pool resources (CPR) -resource systems regardless of the property rights involved, that include natural and human constructed resources in which exclusion of beneficiaries is especially costly, and exploitation by one user reduces resource availability for others- can be managed in a sustainable way. This is the case of the Yanesha natives in the Palcazu basin.

For some years native people from Laguna-Raya have self-organized to manage riparian zones, a common-pool resource. Through the institutional mechanism of a community General Assembly, comuneros have devised a community rule that affirms the need to maintain a fringe of trees along the river bank, and this decision has largely been respected. Comuneros avoided an open access problem by giving individual plots to people. However at some point in time, settlers in Laguna-Raya cut forest along the river to establish their chacras, so degradation of land started to be the result (ex-delegate of Laguna-Raya, personal communication, June 2001). Through "social learning", LagunaRaya comuneros have devised their own rules and are sustaining riparian zones. They faced the problem through communication, and making rules that were discussed through the Communal Assembly. Professional advice could also facilitate the understanding of protection of riparian zones because they provided information that helped identify the problem and the possible solution. 
Because the Yanesha of Laguna-Raya depends on riparian zones for a major part of their livelihood, and because they had some autonomy to make their own access and harvesting rules, these people are more likely than other to perceive benefits from their own restrictions.

\section{Study Objectives and Hypotheses:}

For my study I am proposing to answer the following questions:

- What is the role of riparian zone land use within the overall land use and subsistence strategies of the farmers?.

- Who are the people who use riparian zones? What do they cultivate in these areas, and how are these crops distinct from those grown in uplands?.

- Do people recognize the importance of conserving riparian zones?.

- What drives variations in the amount of protection fringe left?

Based on my objectives my hypotheses are:

- People who arrived first preferentially chose lots along rivers.

- Most newly established households cut riparian zones, and most of the vegetation in riparian zones was cut shortly after the people settled in the place.

- Most of riparian zones are used in general for agriculture.

- Landholders with more land per person leave a greater percentage of riparian zones intact.

- Native people leave a greater percentage of their riparian zones intact than colonists.

- More formally educated householders better recognize the conservation value of riparian zones. 
- Stronger communal structure in native community will result in a greater respect of buffer zones, and awareness of their ecological value. 


\section{CONCEPTUAL LITERATURE REVIEW}

\section{Riparian Zones in the Amazon Basin}

The riparian zone is defined as the transition between the uplands and streams (Svejcar, 1997). Even though the amount of land occupied by riparian zones may be relatively small, they provide very important services on which the ecological integrity and health of the river and upland communities depend. These services include recharging of aquifers, streambank protection, improvement of water quality controlling the rate of sediment entrance (Welsch, 1991; Schiemer and Zalewski, 1992; Bjorkland, 1997; Svejcar, 1997; Brodi et al., 1998). It is important to note that filtration and separation of phosphorus is another ecological service of riparian zones. A portion of $\mathrm{P}$ is trapped and sequestered by the vegetation, while another portion is adsorbed to soil particles and retained (Bjorkland, 1997).

Riparian zones are also crucial to the immobilization and transformation of nitrogen. Excess of $\mathrm{N}$ arises mainly from agricultural activities (fertilizers, animal manure). Riparian zones have been shown to be effective sites for the retention of $\mathrm{N}$ because plants take up nutrients and a good part is lost when nitrate and ammonium are converted to gaseous nitrogen by soil microorganisms (Bjorkland, 1997; Svejcar, 1997; Blackwell et al., 1999). Finally, attenuation of floods, regulation of temperature by vegetation on stream banks, the presence of high rates of biological diversity in riparian zones, their function as habitat and corridors and their cultural and recreational dimensions are additional important aspects (Naiman and Décamps, 1990; Naiman et al., 1993; Bren, 1993; Bjorkland, 1997; Brodie et al., 1998; Blackwell et al., 1999). 
Worldwide, riparian zones are becoming increasingly endangered areas. Almost $70 \%$ of riparian environments in the USA have been removed or severely degraded in the last 300 years. The degradation of riparian environments has deteriored water quality, destroyed habitat, and decreased species diversity. Loss of riparian environments also has caused economic losses because of the decline in some fish populations, increased flooding, and increased sedimentation and other forms of non-point pollution (Bjorkland et al., 1997). In Peru there is little documentation on the degradation or destruction of riparian zones, but it is assumed that in the Peruvian Amazon riparian environments are more intact. This makes it crucial to understand the emerging threats in this region as a baseline for understanding losses in other areas in the Amazon basin, and to begin to raise consciousness now about the consequences of habitat loss.

There has been considerable research on the use and conservation of Amazonian floodplains, know as várzea in Brazil (white water rivers) (Padoch et al., 1999) and riberas in Peru. Floodplains in the Amazon Basin range from the vast floodplains of the lowland Amazon to the narrower and only occasionally flooded shelfs along upland rivers and streams, in the upper montane slopes of the Peruvian Amazon. People who live along floodplains are called ribereños in Peru and caboclos in Brazil. They are rural people including detribalized Amazonian people, descendants of Amazonian-European, Amazonian-African unions, early inmigrants from other areas of Brazil, Peru and other Andean countries (Padoch, 1988).

Research has shown extensive manipulation and associated disturbances of floodplains by local residents in the Brazilian Amazon. Raffles (1999) for example speaks of the "anthropogenic Amazon", and notes three kinds of "non-natural 
disturbance", "human stream construction through manual labor, stream-opening in which both humans and (water) buffalo are involved in the initial clearing process, and erosion induced by the physical impact of buffalo..." (1999: 361). Logging also has a major impact on riparian zones in many areas. The extraction of commercially important species such as virola (Virola surinamensis), mahogany (Swietenia macrophylla), samaúma (Ceiba pentandra), and macacaúba (Platymiscium ulei) has transformed floodplains in the lower and middle Brazilian Amazon regions in particular (Anderson et al., 1999; Albernaz and Ayres, 1999). Smith (1999) notes that cattle and water buffalo ranching have been the main cause of deforestation in the Amazon floodplain. He notes that floodplain forests provide rich fruits, livestock feed, fishbait, construction supplies, fuelwood, and in home gardens.

Land use in riparian zones of the Peruvian Amazon however differs from that of the floodplains of the lower Amazon. Most research on land use in the Andean Amazon has focused on the differing patterns of natural resource use by natives and colonists, as well as the important impacts of access to markets and roads on both groups. Although there is substantial literature on ribereño land use much of it focuses on upland land use with little attention to riparian zones.

In remote regions, riparian zones are used principally for traditional agriculture, with relatively limited development of cattle ranching. For example, Schjellerup (2000) reports that colonists of La Morada community in the Ucayali river (Northeastern, Peru) are dedicated to subsistence agriculture with cattle breeding providing income. In the same region, Hiraoka (1989) finds that ribereños in the community of San Jorge base their economy on farming and exploitation of floodplains. These people manage riparian 
plots that range between 0.3 to 1.2 ha, planting short cycle crops such as corn, beans, peanuts, manioc, and plantain. Hiraoka (1986) also refers the case of Tamshiyacu ribereños (Northeastern, Peru), for whom farming, the main activity, in riparian zones and uplands, is supplemented by fishing, limited hunting, and gathering, enabling the ribereños to satisfy their subsistence and cash needs.

The Amarakaeri natives from the Peruvian Amazon basin (Madre de Dios region) open only one small field per year, because fishing and hunting are their main activities, and they are predominantly oriented toward self sufficiency. However, colonists in the Upper Huallaga clear larger areas than natives do because of their market-oriented agriculture. There are significant intra-group variations, as Bedoya points out, some Machiguenga natives of the Urubamba zone are more dependent on agriculture and less engaged in hunting, fishing, gathering, so they clear more land (Bedoya, 1995). In the same vein, Rudel et al. (2000) point out that the Shuar, acculturated indigenous people from Ecuador, in the Upano valley cleared their land at more rapid rates than do colonist owners of small lands in the 1987-1997 period. But markets do not obliterate significant cultural differences. Rudel et al. note that even though the Shuar had more active participation in markets than the colonists in this area, their fields continued to be more diverse in planted crops than the colonist fields.

The Ecuadorian Chachi natives clear an average plot size of 1.71 ha primarily for subsistence. In contrast, the average plot size for colonists was 43.4 ha and it is dedicated mainly to commercial production and cattle raising (Sierra, 1999). He also establishes that at any given time natives and colonists resource use strategies respond to the relative value of alternative activities and local and external demands for specific commodities. 
Browder (1995) shows that even when Huastec Maya (Mexico) and Rondonia's colonists (Brazil) are oriented to market economies, they clear less land than colonists. However, some colonists because of the interaction through time with their environment are increasing their knowledge about the tropical forest environment and preserving it as the natives do.

For Chibnik (1994) there is considerable socioeconomic variability among ribereños in the Peruvian Amazon. Some ribereños sell rice grown in riparian zones while others rely on tree crops and fruits grown in uplands as major sources of income. Some ribereños combine agricultural labor with festive work parties while others use formally organized groups in which farmers work in on each other's fields on a rotating basis. Padoch and de Jong (1995) found that in Iquitos (Northeast, Peru), the Bora with little access to the market are dedicated mostly to subsistence, having a system diverse in species for satisfying their needs, while Tamshiyacu ribereños with easy access to the market have a highly specialized production in their fields, managing them more intensively.

In the Palcazu basin, where little is known about riparian zones or land use in general, Staver (1989) points out that the Yanesha gain their subsistence from their crop fields in riparian zones and uplands. Riparian zones occupy a small percentage of the landscape and most people in the valley have between 1 to 5 ha per family. These areas are cleared mainly to cultivate corn, beans, peanut, and secondary subsistence crops, which are important sources of protein, vitamins and minerals and which provide variety in the Yanesha diet. 
Inherent differences between colonists and indigenous peoples in their land use and riparian zone practices seem to be heavily conditioned by markets, and access to roads. Indigenous peoples, in general, clear smaller areas than colonists because of a greater diversity in their activities. Colonists, who live in their new regions for a long time start acting more like indigenous peoples. Indigenous peoples next to roads or other access, start acting more like colonists. In remote areas the significant factors for both indigenous peoples and colonists are the degree of access to land, the size of the productive unit, and the availability of family labor. Among colonists and some indigenous peoples, land use and land use change (deforestation) are affected by a high level of market integration; their access to land, labor, capital, and the formal land tenure system.

\section{The legal framework for riparian zone land in the Peruvian Amazon}

The Peruvian General Law of Waters, Law Decree $N^{\circ} 17152$ (Ley General de Aguas) only includes one reference to riparian zones, saying only that the Executive may determine riparian zones or associated areas as reserved for national defense, public services of sanitation, adornment, or other uses. A fringe of 50 meters is mentioned in article $5 \mathrm{a}$ of the law, but in reference to the intertidal zone.

A Presidential Decree of March 1994 (El Peruano, March 27) says that natural or artificial channels of water are property of the State, and owners of lands next to these channels are obliged to maintain "free" a marginal fringe, without further specifications. The same decree also says riparian zones of rivers are prohibited for use for agricultural purposes and human settlement, but no specific width that should be kept free of 
agriculture is given. It has been suggested that the maintenance of a 50 meter fringe, applies equally for all water bodies (Carlos Llerena, personal communication, October 2001). In the Palcazu basin, informants in the Laguna-Raya community reported that they have been told that they are supposed to leave a 50 meters fringe of vegetation along the rivers. However the source of this requirement is not clear.

\section{The Palcazu Basin}

The Palcazu watershed is formed by the rugged Yanashaga range $(3,800 \mathrm{~m}$.) to the west and the lower San Matías range $(1,200 \mathrm{~m}$.) to the east. Located mostly in Palcazu District, Oxapampa Province, and Pasco Department, it covers approximately 95,000 ha. The climate is warm and wet. The temperature is fairly constant throughout the year, with an annual average of $24.3^{\circ} \mathrm{C}$. Precipitation exceeds $2,000 \mathrm{~mm}$ per year (Ordoñez, 2001), however other sources indicate precipitation as high as $6,000 \mathrm{~mm}$ per year. Wet months are from October to April; from May to September it is drier.

The principal river in the valley is the Palcazu which begins at the juncture of the Bocaz and Pichanaz rivers in the southeast part of the watershed. The Palcazu then flows slightly west of north to join the Pozuzo which originates on the west side of the Yanachaga range. Elevation of the Palcazu river is about $400 \mathrm{~m}$ at its beginning, dropping to $270 \mathrm{~m}$. at the confluence with the Pozuzo. The Palcazu is fed from the east by small streams at close intervals coming off the San Matías range. Its major tributaries come from the west such as the Chuchurras and Iscozacin rivers, which are navigable by canoes. The Palcazu is navigable by canoes up to Loma Linda (JRB Associates, 1981). 
There is not much flat land in the Palcazu valley. Most of the flat land is from natural terraces along the larger streams and rivers (Palcazu, Iscozacín, Chuchurras, and Mairo). Soils tend to be highly acid and infertile with high concentrations of aluminum, however some of the alluvial soils are slightly more fertile than the upland soils (JRB Assocites, 1981). Lowlands have sandy soils with high lime amounts, relatively moderate $\mathrm{pH}$, and low aluminum saturation. Uplands have clay-gravel textures, with low $\mathrm{pH}$ and high saturation of aluminum (Salick, 1986).

Approximately $75 \%$ of the lower valley retains its coverage of primary forests. Most of the deforested areas are along the rivers and on the low hills close to these rivers (Hartshorn, 1990). Most of the land in the Palcazu basin is best suited for use as protection forest because of its rugged terrain, fragile soils and high rainfall. Nearly half of the land at low elevations is suitable for forest production, and it is not suitable for any form of cultivation (JRB Associates, 1981).

Pasture is a more restricted land use than permanent cropping because cattle compact soil and their trails can produce erosion. Grazing is only appropriate on gentle terrain with fertile soil. The production of crops such as corn and beans on bare soils with frequent cultivation is too demanding for most of the Palcazu valley. Less than $10 \%$ of the land in the valley floor has sufficient terrain for clean cultivation (JRB Associates, 1981).

There are three protected areas in the Palcazu valley that in total occupy 122,999 ha, of which approximately $50 \%$ are located in the headwaters of the Palcazu basin. The Yanachaga-Chemillén National Park is 111,978 ha and protects high tropical forests. There are no human settlements in the park, however its northern and western boundaries 
frequently are crossed by landless Andean immigrants, in search for agricultural land, and by occasional hunter, fishermen and loggers. The San Matías-San Carlos Protected Forest comprises 145,818 ha. A diverse population lives in this area, mainly settled along the Marginal road, which from the beginning made it very difficult to guarantee the protection of the area's vegetation coverage and the illegal use of its lands. Finally the Yanesha Communal Reserve, with an area of 34,745 ha, acts as a buffer zone between the Park and the local population (10 Yanesha communities) located to the east of the Park. It was established to protect fauna for the benefit of the local population (Plan Maestro Parque Nacional Yanashaga-Chemillén, 1997).

\section{Social History}

\section{Occupation of the Pachitea basin}

The Palcazu population consists of 3 groups, Yanesha native communities, descendants of German Swiss, and Austrian colonists who arrived in Peru 50 to 100 years ago, and recent colonists from other parts of Peru.

Within the last 150 years colonization, economic, interior and foreign policies, agricultural development and infrastructure projects, promoted waves of colonization to the Pachitea basin (Santos Granero \& Barclay, 1998). European migrants were the most dynamic colonist sector until the 1930s. Most arrived under the auspices of the Sociedad de Inmigración Europea created in 1872. Others migrated on their own or under immigration agreements signed between the State and private organizations. The main reason for migration was the search for employment, which migrants attempted first on the coast or in the highlands (Santos Granero \& Barclay, 1998). These migrants gradually 
started to cultivate and expand their cultivated lands requiring labor from the highlands, which they obtained primarily under the enganche system by which they recruited laborers advancing some money or goods. This system became widespread because of the expansion of the coffee economy since the 1890s, involving large contingents of Andean laborers each year. Beginning in the 1930s, these migrant laborers started invading the uncultivated lands of large concessions. In this social context, local natives who at the beginning resisted participating in the nascent mercantile economy of the area, no longer could isolate themselves from the processes unleashed by colonization. Increased material needs and the debt-peonage system gradually led to a growing number of native families to work for the colonists in exchange for payment in manufactured goods. Also as a consequence of the large-scale occupation of the earliest colonized areas, natives began to abandon their traditional pattern of dispersed settlement and to gather in small areas surrounded by colonist lands (Santos Granero \& Barclay, 1998).

In the Palcazu Valley, a subsidiary of the Cerro de Pasco Corporation conducted oil explorations during the 1950 s, which produced a new wave of speculative land claims. By 1958, all the accessible lands in the Palcazu Basin, traditionally home of the Yanesha, had been claimed by colonists. Only one Yanesha faction, an Adventist group settled in Loma Linda on the Upper Palcazu, had filed a land claim in 1944 for 2000 ha. However, most of their land claims were abandoned in the 1960s when the Cerro de Pasco Corporation withdrew from the area. 


\section{Communal and colonist land tenure}

There are two types of land tenure in the Oxapampa Province, one for colonists and another for native communities. The native communities are groups of indigenous people for whom the State has recognized ancestral rights through property titles in a communal form. The colonists were settled in the edges of rivers in the Palcazu valley, occupying the best agricultural lands. Recent colonists, mainly of Andean origin, occupy valley hillsides. The first ones have property titles, the second ones have possession certificates (Plan Maestro, 1997).

Between 1967 and 1972, encouraged by community development workers of the Agrarian Reform Program, the Yanesha pressed the government to recognize their land claims with a community title for each settlement (Smith, 1982).

Between 1975 and 1980, the majority of native settlements in the Central lowland rainforest were registered legally; later the registration of native communities slowed. However, by 1989 the majority of native settlements in the region had been registered (Santos Granero \& Barclay, 1998). Land rights of Amazon indigenous have been legally unstable during the last 40 years. In 1957, by means of Supreme Decree \# 003 for first time in the republican legislation, lands were reserved in favor of the lowland rainforest tribes.

The Agrarian Reform Law (Ley de Reforma Agraria (15037) promulgated in 1964, did not affect lands currently occupied by natives that were sufficiently large to their needs. It also took into consideration the possibility of granting the property outright to indigenous peoples. However in practice it was not carried out. On the contrary, the 
law generated one of the most aggressive colonization and occupation processes in the history of native lands.

The law of Native Communities and Agricultural Development of the Selva (Ley de Comunidades Nativas y De Desarrollo Agrario de Selva y Ceja de Selva), D.L 221751978, states that a Native Community has rights to territorial property, and their lands are inalienable. Article 11 states that forestlands within a community territory cannot be titled, but only ceded in usufruct to the community. The Peruvian Political Constitution of 1979 grants legal recognition to the native communities in its article 161, and declares their lands inalienable, unless a two-thirds majority of the community agrees to dissolve the communal land holdings in its article 163.

In 1993, the Peruvian government by Legislative Resolution (2653), ratified the 169 ILO (International Labor Organization) pact about tribe and indigenous people in independent countries, in which there is a commitment to recognize the property and posession rights of natives over the lands they occupy by tradition.

The current Peruvian Political Constitution (1993) annuled the inalienable principle of communal lands, determining that abandoned lands can revert to the government domain for later transference to private owners. 


\section{METHODS}

To reach my objectives I gathered data through a survey of 79 settler households and ethnographic study in a native and a colonist community in the Palcazu basin, Central Amazon Peru, between May 18 and July 17, 2001 (see map 1). These two communities are socially mixed but they still are characterized as native and colonist on the basis of land tenure.

\section{Study area}

* Laguna-Raya, is one of the three sectors of the Loma Linda-Laguna Native Community. Raya is also the name of the stream that runs through this sector. The stream, bounded by gentle slopes, is relatively narrow (20m in average) and shallow. In some places people can cross the stream by wading. Soils are sandy, with an average $\mathrm{pH}$ of 5 (Salick, 1986). Laguna-Raya consisted of 60 families when the interviews were applied.

* Santa Maria, is a colonist settlement considered as an anex of the town of Iscozacín. It is a little higher in the valley, and its topography is more rugged than in Laguna-Raya. The Palcazu river, which runs through Santa Maria, is wider than Raya $(35 \mathrm{~m})$, and it is deep, which is why people need a raft to cross the river. Soils are sandy, with an average pH of 4.5 (Salick, 1986). Santa María consisted of 21 families when the interviews were applied. 
Map 1: Location of Studied communities

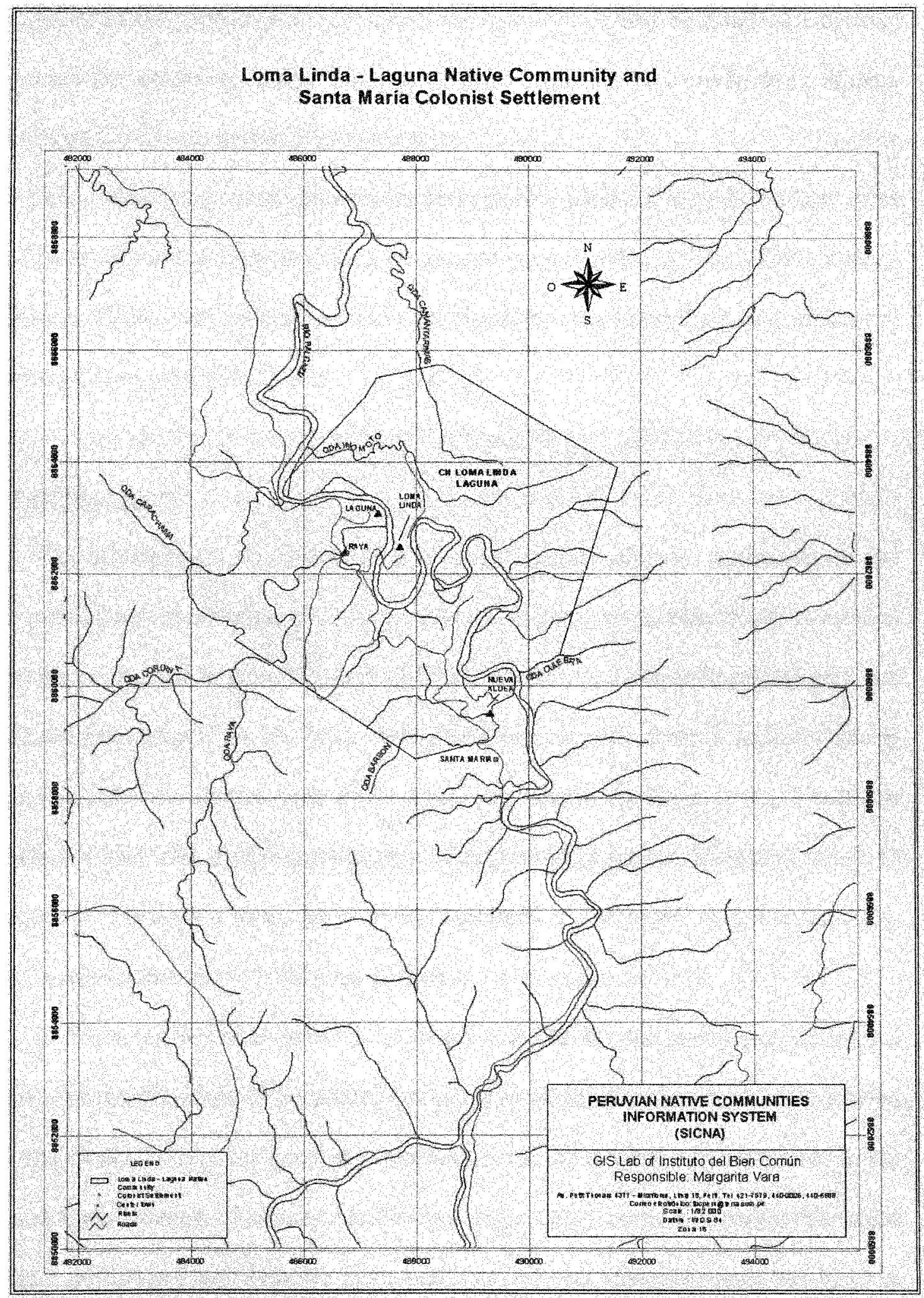




\section{Sampling frame}

Because the population in my study area consisted of only 81 families, I decided to interview the entire population. The questionnaire applied to 79 households ( 2 of them did not want to be interviewed) is thus a census.

After identifying which households had riparian access, I identified where there were chacras (agricultural fields) along rivers, and mapped them. I took a GPS point in the middle of the parcel in riparian zones, estimated the area of the field, and took notes of the crops there (appendix 1).

\section{Ethnographic study}

The ethnographic study consisted of observations, informal conversations and unstructured interviews with householders about their conceptions, classification, and use of riparian zones, and in general about all their activities. In Laguna-Raya this part was carried out from May 19 to 30, 2001, while I was mapping the chacras, and also during the period were the census was done. Upon my arrival in Raya town, I met the Communal Chief who is also the Delegate of Laguna-Raya sector; he invited to me to participate in Saturday's mass, where I was presented to the people of the community. There I arranged interviews with some of them.

In Santa Maria, I intended to do something similar, but the reality was different. I did not meet the Teniente Gobernador, the authority of the community, when I arrived there; the General Secretary gave me information on the number of households in the area and their location. Because colonists are dispersed, I could not follow the same strategy I applied in Raya. Another factor was that in Santa María householders had just 
enough time to answer the questionnaire, but not for informal conversations, so there I just talked with the Teniente Gobernador and I spoke briefly with some colonists.

\section{Application of structured interviews (data collection)}

This phase was carried out from June $11^{\text {th }}$ to July $11^{\text {th }}$, 2001. Interviews were applied to the householders and considered use of riparian zones, economic activities and factors affecting these activities, and respondent's data (social group, education, occupation, land tenure) (questionnaire in appendix 2).

The ethnographic research revealed that the General Assembly of the LagunaRaya community had at an undetermined time in the past agreed to leave a forest fringe of 50 meters as protection (variable according to personal communications) along rivers, and beyond this fringe they establish their chacras of 25 to $50 \mathrm{~m}$ long, I decided to define riparian zones in a more cultural way according to their use. So for my study, riparian zones are "areas located from the river shore until 100 meters of width".

At this point I had a map of the location of chacras in riparian zones in LagunaRaya, so I started the interviews with people who were cultivating these places because riparian zones were the main objective of my study.

I started interviewing the person with the farthest chacra from my lodging, this meant 2 hours and 15 minutes by walking from the town. Because of the long distances I could interview on average 5 people per day. Some days when it was raining, some people stayed at home in the town, so I interviewed them there.

I applied the questionnaires mainly from Monday to Friday when people were at their chacras, because on Saturdays they would not speak to me because of their religion. 
Also on Sundays, they have communal meetings in the morning, and in the afternoon they play soccer and volleyball. So it was not possible to talk with them, and I tried not to alter their activities because of my work.

Sometimes when I could not find the householders in their chacras I had to return to interview them, and in two cases I interviewed the householder's wife because the husbands were not present in the community when I applied the interview.

In Santa María, as in Laguna-Raya, I was lodged in a fixed place, which was my initial point. I started interviewing people with lands bordering the river. Here distances were also long, so I could interview 3 people per day during the weekdays. During one weekend I went back to Raya to finish the interviews with people I could not find at the respective time.

\section{Processing of data}

I used SPSS statistical software to process the information from the interviews. Descriptive statistics were derived for all quantitative variables, and frequencies (percentages) for all qualitative variables. To compare variables between the two communities, I used an Independent Sample T-test, with a significant level of 0.05.

Some qualitative variables expressed as proportions were recoded as dummy variables, and then compared through an Independent Sample T-test to check for significant differences between proportions in these two communities. Such variables recoded were crops in riparian zones, crops in uplands and percentage of people with access to riparian zones, people that develop agriculture in uplands, and importance of riparian zones. Householder education levels were also recoded, so for example the 
original answers were: non-literate, incomplete primary, complete primary, incomplete secondary, complete secondary, incomplete superior and complete superior. I recoded these categories considering number of schooling years: $0,3,6,9,11,13$, and 16 . 


\section{RESULTS}

This section of the thesis is based on the ethnographic study and the survey. I will present relevant data on the formation of both communities investigated in my study: Laguna-Raya and Santa María. Also general aspects of life style, and description of the activities carried out in these communities will be presented. I pay special attention to agriculture as the main activity in the area, and more specifically to riparian zone land use. Since I spent more time in Laguna-Raya, more information is presented on this community.

\section{RESULTS FROM ETHNOGRAPHIC STUDY}

\section{Laguna-Raya Sector}

The Yanesha native community of Loma Linda-Laguna, which includes the Laguna-Raya sector (independent territorial sub-unit in a native community; in practice each sector is a different community with a Delegate as the Chief) is located on both margins of the Palcazu river. The Yanesha, an Arawak speaking group, have inhabited the Pozuzo, Oxapampa, and Chanchamayo valleys until 1900, but during the last 100 years they have retreated to the low Palcazu valley (Richard Smith, personal communication, May 2001).

This community borders on the San Matias-San Carlos Protected Forest and the Yanesha Communal Reserve. It has an area of 5,776 ha and has been divided in 3 sectors: Loma Linda, Laguna-Raya, and Nueva Aldea. Laguna-Raya, which has a population of 343 people according to INEI (2001) is $85 \mathrm{Km}$ from the town of Villa Rica, the nearest 
market town with a population of 14,739, and it is at an altitude of 307 masl (GPS point on Raya's bridge).

The current population distribution of what is called Loma Linda-Laguna and the emergence of the so called sectors has been determined by religious, personal and family differences, migratory patterns, and government programs. The community was founded in 1948 with the original name of Tsacam (firefly) in the present Loma Linda sector by a group of Adventists from the Perené river region. In 1953 the Adventist pastor Fernando Stahl named the community Loma Linda after the California city of the same name that is a US center of Adventism; it was a very isolated community that sought to attract Adventists. As soon as the Yanesha population began expanding in the lower part of the Palcazu valley, foot traffic began to increase between the lower and upper zones of the valley, passing through Cacazú. As a way to earn money, many of these people migrated to harvest coffee in Cerro Pampa, a German settlement between Puente Paucartambo and Villa Rica (Personal communication, Richard Smith, May 2001).

In early 1970 people from Alto Yurinaqui (La Merced) and from Tsachopen (Oxapampa) started to settle at a location across the Palcazu river from Loma Linda now called Puerto Laguna. By 1973-74 the Puerto Laguna settlement began to distinguish itself from Loma Linda. Puerto Laguna's brand of Adventism was more open, more liberal, not as close to the church ideals. This created an internal division in the church leading to two different forms of Adventist worship in the community today. There were also other internal problems in the community: Loma Linda was under the control of two founding families. The new people did not want to be under the power of older families, thus producing a division and the founding of the Puerto Laguna sector. In 1974 the 
government gave a title as a Native Community to Loma Linda but people from Puerto Laguna refused to accept it. This problem continued for some years until a general agreement was produced between the two villages, and the community finally got its title in 1984. Nueva Aldea, the third sector of Loma Linda-Laguna, was founded more recently by migrants from Cacazú (Personal communication, Richard Smith, May 2001).

In 1980 the Pichis-Palcazu Special Project (PEPP), a large scale colonization and development project in the Palcazu valley, began opening the Marginal Villa Rica-Puerto Bermudez road. However with the opening of the road many things changed: people from Puerto Laguna started to move closer to the road. The PEPP established its base on the road so this brought also merchants. In this context, the town of Raya was settled in 1982 approximately, but was not formally recognized until 1994. Also with the establishment of the road there was a movement of people to Alto Raya, possibly to escape pressure from colonists.

The process of fission within Loma Linda-Laguna continues. Currently people from Laguna-Raya Sector want to separate from the other sectors because of internal disagreements. When the community has to carry out some bureaucratic procedure, they have to collect money among all the members of the community. However the only members who always contribute to communal cash needs are people from the LagunaRaya Sector. Internal tensions are also currently exacerbated by accusations that the current Loma Linda Delegate has commited sex crimes. Now people from Raya are researching the procedures for getting individual titles, they do not want to be a community because of internal problems and because as a community they can not ask for loans from the Agrarian Bank. They have decided to ask the Agricultural Ministery to 
parcel their lands, with obvious implications for current patterns of communal land management and possibly for riparian zones.

\section{The formation of the community}

The Native Community as a form of organization is new for the natives; before they organized at the level of domestic units grouped by kinship. The household was generally composed of sons and son-in-laws with their own house and chacra, but in the same compound around the parents. The concept of working in groups that include families they are not related to is something new. The need to form larger communities organized on a territorial basis arose as a political strategy for defending their lands against a massive fast moving invasion (Personal communication, Richard Smith, May 2001).

\section{General characteristics of the community}

Loma Linda-Laguna is the only Adventist community in the Palcazu valley (Personal communication, Richard Smith, 2001). It is directed by a Communal Chief (Jefe), and each of the sectors is administered by a Delegate. Traditionally the chief or

delegate was elected by lineage, and behavior by public decision among the members of the community ("comuneros"). However since this year (2001), as a way to democratize the process, the assembly decided to call for elections and choose the delegates. The delegate is chosen for a period of 2 years, with his main functions to manage community needs and correct the behavior of comuneros. If somebody steals, commits adultery or 
rape, the punishment consistes of tying the guilty party to a trunk full of tangarana ants for 30 seconds, producing great pain to the offender.

There is an internal statute that governs the community, and there are communal assemblies, of variable frequency, where the Communal Chief discusses pending topics with the participation of the entire community.

The social composition of Loma Linda-Laguna has shifted in recent years. Not all the population in Laguna-Raya are natives. With the construction of the road (Villa RicaPuerto Bermudez) and the presence of the PEPP, colonists came from other parts of the country. Some of these people settled in Laguna-Raya and married native women. After 5 years of living in the place they could become comuneros, and after 2 or 3 years they may have asked for a parcel of land.

Laguna-Raya lacks basic services. There is no electricity, running water, or sewerage. The scarcity of latrines in most houses is noteworthy. There is a health post without basic medicines; most comuneros can not afford the cost of adequate medical treatment when they fall ill or have an accident.

Almost all children in the community attend school. There is a kindergarten, a primary school and an agricultural vocational school, the only secondary school in the community. There is a legal obligation to teach the Yanesha language to the children in the school, on the basis of an agreement between the community and the teachers, sanctioned by the General Assembly. The majority of the students study during the week and during weekends they help their parents in agricultural labors. The economic situation does not allow parents to buy required materials for the classes, so possibilities for education are limited. However, some communeros with higher income can afford the 
cost of higher education, and some of them have sent their children out of the community to continue their studies.

Religion is an important aspect in Laguna-Raya people's lives. Most of people are Adventists, and some of them meet every Saturday in the church in Puerto Laguna or in Loma Linda and do not engage in any labor. Because of their religion they do not eat the meat of animals that have cloven hooves, such as collared peccary (Tayassu tajacu), white-lipped peccary (Tayassu pecari), lowland tapir (Tapirus terrestris), paca (Agouti paca), or fish without scales and fins.

\section{Land Common property institutions and land tenure}

There is a communal title for the entire Loma Linda-Laguna community. The distribution of land among comuneros is determined by decision in general Assembly where the Delegate establishes the limits for each comunero. At the age of 15 , all adult males in the community automatically become a comunero with rights to a parcel of agricultural land.

Originally, the average land grant each comunero received was 30 ha by community decision. Due to an internal agreement, each comunero received 300 meters of width along the lowest lands and 1000 meters of length uphill for agricultural purposes (30 ha). People who developed cattle raising were given 30 additional hectares, this mean $600 \mathrm{~m}$ by $1000 \mathrm{~m}$ ( $60 \mathrm{ha}$ ). From the $1950 \mathrm{~s}$ to the 1970 s each comunero chose where he wanted to live and establish his chacra (agricultural field). However, in the last couple of decades because of population growth, the amount of land assigned has been variable and 
less than it was before; it depended on the amount of land available in the community, consisting primarily of uplands.

As a result of this, the more recent comuneros have their lands located farther from the town of Raya ( 45 minutes to $1 \frac{1}{2}$ hours by foot), so as a consequence some comuneros seek agreements with parcel-holders closer to town. Under these agreements, the comunero with land near the town gives a parcel of his land to the other comunero to plant his crops. After the harvest the arrangement finishes, and the parcel returns to the original owner. This is thus a share cropping arrangement where the products of the harvest are distributed between the two parts and is generally only arranged between relatives. The Delegate does not participate in this agreement, although he will be advised of the arrangement.

\section{Economic activities}

The Yanesha have maintained a subsistence economy based on fishing and the cultivation of a small number of crops. Raising of chickens, hunting and gathering are complementary activities, and cattle raising is not widely practiced. Traditionally, the Yanesha did not establish many chacras along rivers, in riparian zones; they mainly sowed manioc in the uplands and most of their time was spent in fishing and hunting. According to the Communal Chief "with education our parents started to sow in a fixed place".

Agriculture: Agriculture is the most important economic activity among the Yanesha. The main crops are manioc (Manihot esculenta) the most important plant food, plantain 
(Musaxparadisiaca), pituca (Colocasia esculenta), corn (Zea mays), beans (Phaseolus vulgaris), peanut (Arachis hypogea), rice (Oryza sativa) and fruits. In Laguna-Raya and in general in the Palcazu valley, Yanesha agriculture is for subsistence. It is restricted by the lack of land in floodplains and thus depends on the use of abundant lands but poorer upland soils.

The Yanesha from Laguna-Raya do not have easy access to the nearest markets in the towns of Iscozacín and Chatarra because of prohibitely high transportation costs. Some small products are sold in the town (Raya) to local stores and restaurants, to buy basics such as salt and soap and for covering the costs of education for their children (uniforms and materials). However the production in their chacras satisfies their consumption needs.

Agriculture in Uplands: Uplands produce few crops. The main crops are manioc and plantain. Depending of the variety, they can be harvested at different times. For example, white manioc can be harvested as early as 8 months, while yellow manioc is harvested as late as 1-2 years. Something similar occurs with plantains, which can be harvested as early as 9 months or as late as 2 years. Thus, these products can be "stored" in situ for long periods. Other crops sowed in the upland part are squash, sweet potato, papaya, citrus, coffee, and pijuayo.

The average annual area used per household in the uplands is $1 \mathrm{ha}$, and according to the comuneros production on soils where primary forests stood is good, even sowing corn in the first year or two, but in secondary forest the production decreses, with these lands being good only for manioc. 
The general system of the Yanesha is a variety of slash and burn in which they cut an area of forest (usually early secondary forest), burn it and plant their food crops. Usually after one year the site is abandoned because of decrease in soil fertility and invasion of weeds, and a new plot is cut. This new plot is located close to the abandoned site, and between these two plots is left an edge of forest (10m approximately). They do a sort of circle, and after 4 years of fallow the abandoned site is reused again.

Agriculture in riparian zones: According to the comuneros riparian zones or "cementeras" are places close to rivers, running from the river edge to the high water mark during floods. There is not a specific distance from the edge of the river, but in Laguna-Raya the floodplain averages 100 meters. There appears to be no further native classification of riparian zones, but the riparian zones are clearly important because of the renewable fertility of the soils and the richness of the fisheries. The principal problems associated with riparian zones are the unpredictable ocurrence of floods and the decline in fish catches during the rainy season, when the volume of water makes fishing very difficult.

In general, people who settled in Raya later do not have chacras in riparian zones. However, in Puerto Laguna there is an extension of approximately 150 ha of riparian zones for communal use (ex-Delegate Laguna-Raya, personal communication, June 2001), so every comunero can have access to a plot of $50 \times 50 \mathrm{~m}$ in these zones if he requests this from the Delegate of the sector. The only condition is that in riparian zones it is not permited to sow permanent crops, such as coffee or trees; only annual crops are allowed. This is decided in an assembly where all the community participates, and the 
Delegate exerts control of this. If in certain period somebody does not cultivate his parcel in the riparian zone and another person needs this for his crops, he only has to ask for permission to this person.

Some comuneros stated that riparian zones are planted once per year, during MaySeptember. The high fertility of these areas induces farmers to plant crops of short growing season that mature in three or four months. According to an engineer from Pronaturaleza, an NGO working in Raya, riparian zones after harvesting are left in fallow for two years. The period of harvesting depends on the variety, and according to one informant the average area used in these zones is $0.25-0.50$ ha.

A strip of trees along riparian zones is left as a way of protection for avoiding erosion of land when the river floods. This practice appears to have both traditional and contemporary sources. Informants report that parents told them they should leave trees along the river, and they also report having heard about the practice from agronomists who have visited the place. One informant said that they leave a strip of trees that ranges between 20 to 30 meters. The width of this fringe was established by internal agreement in assembly, but it is not considered in the Communal Statute.

The main crops sowed in riparian zones are listed in Table 1. 
Table 1: Principal crops in riparian zones in Laguna-Raya

\begin{tabular}{|l|l|r|}
\hline \multicolumn{1}{|c|}{ Crop } & \multicolumn{1}{|c|}{ Sowing month } & $\begin{array}{c}\text { Harvesting period } \\
\text { (months) }\end{array}$ \\
\hline Close to river edge & Feb-April* & $3-5$ \\
\hline Corn (Zea mays) & Feb-April* & $2-4$ \\
\hline Bean (Phaseolus vulgaris) & Feb-April & $2-5$ \\
\hline Peanut (Arachis hypogea) & Farther from river edge & $8-10$ \\
\hline Manioc (Manihot esculenta) & Any time of the year & $6-12$ \\
\hline Plantain (Musaxparadisiaca) & Any time of the year & $4-5$ \\
\hline Pituca (Colocasia esculenta) & Any time of the year & \\
\hline
\end{tabular}

*There is variation in this, the predominant period is February-April, but some people plant in April-May.

Typical combinations of crops in riparian zones are corn with peanut or corn with beans, and farther from the edge (approximately $50 \mathrm{~m}$ from the edge), plantain with manioc and pituca are planted.

Crops in riparian zones include 4 varieties of plantain (largo, seda, isla, bizcochito), 2 of peanut (red and white), 3 of corn (yanesha or yellow, maiz de afuera, hybrid), 3 of rice (carolina, aguja, chino), 3 of manioc (white, nevate or yellow, pucallpina), and 3 of sweet potato (purple, yellow, white). The most important agricultural production is in riparian zones because people can sow crops (corn, beans, and peanut) that are important for autoconsumption, and also for feeding poultry (such as corn). Other crops that are sowed in these zones but in smaller amounts and frequency are avocado, watermelon, squash, papaya, sachapapa, and sweet potato. 
The most common plant species found in the protection fringe (strep of trees along river) in riparian zones are shown in table 2 . The identification of these species are based on common names not in vouchered specimens (Identified by a dendrologist working for Pronaturaleza)

Table 2: Plants species in riparian zones in Laguna-Raya

\begin{tabular}{|l|l|}
\hline \multicolumn{1}{|c|}{ Common name } & \multicolumn{1}{c|}{ Scientific name } \\
\hline Requia & Guarea sp. \\
\hline Oje & Ficus moxima \\
\hline Shimbillo & Inga sp. \\
\hline Pashaco & Parkia sp. \\
\hline Caña brava & Gynerium sagittatum \\
\hline Bombonaje & Cardulovica palmata \\
\hline Heliconia & Heliconia sp. \\
\hline Chuyachaqui caspi & Chrysochlamys weberbaueri \\
\hline Topa & Ochroma pyramidale \\
\hline Piper & Piper sp. \\
\hline Ocuera & Vernonia sp. \\
\hline Oropel & Erythrina ulei \\
\hline Bobinsana & Calliandra sp. \\
\hline Peine de mono & Apeiba tibourbou \\
\hline Retama de selva & Senna silvestris \\
\hline Atadijum & Trema micrantha \\
\hline Pashaco & Macrolobium sp., Parkia sp., and \\
\hline Schizlobium sp. \\
\hline Croton draconoides \\
\hline
\end{tabular}


Livestock: Livestock, particularly backyard animals, is one of the most important economic activities in the community. Because the area has been overhunted, population has developed the raising of small livestock such as chickens, turkeys, ducks, pigs, and goats.

During December-February, when there is less fish or bushmeat, people consume more chicken. Also some chickens are sold during the school year to buy uniforms and supplies. Some people sell chickens when they have needs to cover. Thus, chickens are the principal source of cash and an indicator of relative wealth. However during the field work period, the chicken population decreased because in January and February of 2001 there was an epidemic of cholera among the domestic chicken population.

Hunting and fishing: A variety of game is hunted, however the amount of animals has decreased with time because of overhunting, but there are still some abundant animals such as paca (Agouti paca), agouti (Dasyprocta sp.) armadillo (Dasypus novencinctus), and monkeys, because the majority of the members in the community are Adventists, so they are restricted by religion from eating these animals, a factor of conservation in this area.

Few people in the community have a firearm, so those who do not have a firearm often borrow one from a friend or relative. In exchange for its use, the hunter supplies the ammunition and the meat is divided equally with the owner. For hunting small animals such as rodents or birds, they put manioc or grain as bait in the trap. This is done in the evening, and the next morning they check the trap. The pyramids shaped traps are made by tying twigs and vines. 
Fishing is other important economic activity for subsistence in the community. Fish is an important source of animal protein in the area; however, it is becoming a scarce resource. Although fishing is done at all hours, it is most common in the late afternoon and night.

The most abundant and consumed species are carachama (Pterygoplichthys multiradiatus) and chupadora or boquichico (Prochilodus nigricans). The common names of other species are: anchoveta, bagre, anashua, lisa, barbon, anguila, sungaro, and paco. Fish is consumed in greater quantities in the summer because this is the main season for this activity. In December-February the river rises, and it is the period of fish scarcity.

Gathering: A large variety of plant parts, wood, and fruits are collected mainly for subsistence. Medicinal plants are collected mainly from primary forest. One comunero told me that he collects them during full moon because the plants have more active principles. The most common medicinal plants and their uses are shown in Table 3 .

Table 3: Common medicinal plants and their uses in Laguna-Raya $(\mathrm{N}=27)$

\begin{tabular}{|l|l|l|}
\hline \multicolumn{1}{|c|}{ Common name } & \multicolumn{1}{|c|}{ Scientific name } & \multicolumn{1}{c|}{ Use } \\
\hline Sangre de grado & Croton spp. & Cough and wounds \\
\hline Matico & Piper spp. & Inflammations \\
\hline Uña de gato & Uncaria spp. & $\begin{array}{l}\text { Any disease, rheumatism, ulcers, } \\
\text { muscles pain }\end{array}$ \\
\hline Chuchuhuasi & Maytenus spp. & Cold, ulcers, muscles pain \\
\hline Agua de plátano & Musa paradisiaca & Bronquios and lung \\
\hline Yantén & Plantago spp. & Back pain \\
\hline
\end{tabular}




\begin{tabular}{|l|l|l|}
\hline Sachamani & Plukenetia volubulis & Upset stomach \\
\hline Renaquillo & Clusia rosea & Hits \\
\hline Piripiri & Cyperus spp. & Snake bites \\
\hline Sacha jergón & $\begin{array}{l}\text { Dracontium lootense, } \\
\text { Urospatha sagittifolia }\end{array}$ & Snake bites \\
\hline Renaco & Ficus spp. & Bone soldering \\
\hline Ojé & Ficus maxima & Parasites, purges \\
\hline Clavohuasca & Tynanthus panurensis & Ulcers \\
\hline Sachaajo & Petiveria alliacea & Cold \\
\hline
\end{tabular}

\section{Santa María Annex}

Santa María, a town of colonists considered as an annex of Iscozacín, is located on one of the margins of the Palcazu river, close to the Nueva Aldea sector in the Loma Linda-Laguna Native Community. It is at an altitude of 393 masl (GPS point took at the school), and has a population of 353 people (INEI, 2001).

It was a colonist settlement for several years, but three years ago it was assigned as an annex of Iscozacin with a Teniente Gobernador as the authority of the place, responsible for enforcing laws and representing the community in many of its dealings with other communities. The governor of Iscozacín (a regional political official) named the current Teniente Gobernador for a period of two years, but he has been in office now for almost 3 years. To choose a new Teniente Gobernador, the community will select three nominees for the position, and the Governor of Iscozacín will have the ultimate responsibility for choosing the new Teniente Gobernador for Santa María. 
The way people started to settled down in Santa María was that during the colonization process of the lowland rainforest, people interested in having lands in this place took free lands and started to work them. Generally after a period of three years, they claimed these lands to the Agricultural Ministery, and they were given a provisory title, which was fixed some years later. Just last year, colonists in Santa Maria who possessed some title for their property received their legal title with the final delimitation of their lands.

The first colonists who took posesion of Santa Maria were people from the highlands and lowland rainforest, but lately some Yanesha in the area left their community and asked for a land in Santa María.

At the beginning no towns or nucleated settlements were formed by the farmers. Rather a pattern evolved in which the chacras of the colonist were spread along the road, so each farm family lived and worked on a single plot of land. Today this pattern continues, but also some people build their houses close to the health post and primary school.

Because the current Teniente Gobernador felt that Santa Maria was an isolated settlement, he decided to join to FECONAYA (Yanesha Native Communitivies Federation) two years ago to receive some support.

There are some internal disagreements between the members of the community; because of this some colonists in the annex do not want to be part of it, they say they belong to Santa Rosa, the native community close to this town. 


\section{Economic activities}

Colonists in Santa María maintain basically a subsistence economy because transportation costs are high. Its economy is based on the cultivation of some crops, the raising of animals, and the complementary activities of fishering and hunting.

Agriculture: Agriculture is the most important economic activity. The main crops planted and the way how this activity is carried out is similar in some of its general features to the natives from Laguna-Raya. The main crops sowed in uplands are manioc and plantain, and depending on the variety they can be harvested as early as 8 months or as late as 2 years.

Agriculture in riparian zones: People in Santa María call riparian zones the beaches and edges of rivers, and there is no classification for them. A strep of trees along riparian zones is left as a way of land protection. The width of this fringe is stated in the property titles. Most of people in Santa María have access to riparian zones, however people who arrived later could not obtain lands close to the river. The typical crops sowed in riparian zones are corn, manioc, plantain, and pituca (Table 4). Other crops are cacao, avocado, coffee, pijuayo, citrics, and pineapple. 
Table 4: Crops in riparian zones in Santa Maria

\begin{tabular}{|l|l|r|}
\hline \multicolumn{1}{|c|}{ Crop } & \multicolumn{1}{|c|}{ Sowing month } & $\begin{array}{r}\text { Harvesting period } \\
\text { (months) }\end{array}$ \\
\hline Close to river edge & March-April & $3-4$ \\
\hline Corn (Zea mays) & March-April & 3 \\
\hline Bean (Phaseolus vulgaris) & Farther from river edge & 1 year \\
\hline Manioc (Manihot esculenta) & Any time of the year & 1 year \\
\hline Plantain (Musaxparadisiaca) & Any time of the year & 6 \\
\hline Pituca (Colocasia esculenta) & Any time of the year & \\
\hline
\end{tabular}

Combination of crops in riparian zones is corn with peanuts, beans or pituca. There are 2 varieties of pituca (sandilla and white), 3 of peanut (red, white and chispeadito (white and purple)), 4 of plantain (largo, seda, isla, and bizcochito), 2 of manioc (yellow and white with purple peel).

Livestock, hunting, fishing, and gathering: The raising of small livestock such as chickens, ducks, cuyes, and pigs is an important economic activity in Santa María. Most of people grow chicken, and it is consumed at any time of the year.

The main game hunted is paca. Hunting is exclusively for consumption, and it is done mainly in primary forests and chacras. Sumer is the period of more hunting.

Fishing is other important economic activity for consumption. All the people in the community practice this activity mainly once per week. The main fish caught are Corvina (Salminus affinis) and carachama (Pterygoplichthys multiradiatus); other species 
are and sabalo (Brycon sp.), chupadora (Prochilodus nigricans), barbon, sungaro, doncella, and anchoveta.

Gathering is a complementary activity for some people in the community. The main products collected are fruits and medicinal plants. The most common medicinal plants and their use is shown in Table 5.

Table 5: Common medicinal plants and their uses in Santa María $(\mathrm{N}=11)$

\begin{tabular}{|l|l|l|}
\hline \multicolumn{1}{|c|}{ Common name } & \multicolumn{1}{|c|}{ Scientific name } & \multicolumn{1}{c|}{ Use } \\
\hline Ajo de monte or sacha ajo & Petiveria alliacea & Cold \\
\hline Sarzaparrilla & Smilax sp & Skin irritation (infection) \\
\hline Uña de gato & Uncaria spp & $\begin{array}{l}\text { Inflammation, cold, } \\
\text { rheumatism }\end{array}$ \\
\hline Chuchuhuasi & Maytenus spp & Cold, rheumatism \\
\hline Abuta & Abuta sp & Malaria \\
\hline Cascarilla & Ladenbergia magnifolia & Rheumatism \\
\hline Copaiba & Copaifera sp & Hits \\
\hline Clavo huasca & Tynanthus panurensis & Cold \\
\hline Plano & N/N & Hits \\
\hline
\end{tabular}




\section{RESULTS FROM SURVEYS}

\section{Householder characteristics}

The social composition of Laguna-Raya has shifted in recent years. Eighty-six percent of the inhabitants are Yanesha natives, 34.5\% of them were born in the Loma Linda-Laguna native community and another $51.7 \%$ are Yanesha who migrated from Pozuzo, Oxapampa, and Chanchamayo valleys because of colonization pressure. Fourteen percent are colonists who arrived in the community since the opening of the Marginal Villa Rica-Puerto Bermudez road in 1983. Most of these people were employers of the Pichis-Palcazu Special Project who married native women and became comuneros. In Santa María, $71.4 \%$ of the inhabitants are colonists who arrived mainly from other parts of the lowland rainforest with the opening of the Marginal road; only one person was born in the community (4.8\%) and $28.6 \%$ are Yanesha natives who left their community, mainly Loma Linda-Laguna, in search of their own land, and because they did not want to continue participating of the communal works, which they considered not to be for the future benefit of their children.

Table 6: Origin of householder $(\mathrm{N}=79)$

\begin{tabular}{|c|c|c|c|c|}
\hline \multirow[t]{2}{*}{ Origin of householder } & \multicolumn{2}{|c|}{ Laguna-Raya $(\mathrm{N}=58)$} & \multicolumn{2}{|c|}{ Santa María $(\mathrm{N}=\mathbf{2 1})$} \\
\hline & Freq & $\%$ & Freq & $\%$ \\
\hline Native & 50 & 86.2 & 6 & 28.6 \\
\hline Colon & 8 & 13.8 & 15 & 71.4 \\
\hline From the Highlands & 2 & 25.0 & 4 & 26.7 \\
\hline From the Jungle & 4 & 50.0 & 11 & 73.3 \\
\hline From the Coast & 2 & 25.0 & & \\
\hline
\end{tabular}


The mean age of household heads in Laguna-Raya was 42 years at the time of the survey, while in Santa Maria it was 44 years. People who migrated from other communities to Loma Linda-Laguna in average are settled in the community 21 years, so they were approximately 21 years old at the time of their arrival to the community. In Santa María, colonists are settled in the area 11 years, so they were approximately 33 years old at the time of arrival to the community. Household size is bigger in Laguna-Raya than in Santa Maria. In the native sector the average is 5 members, ranging from 1 to 11 , while in the colonist town the average is 4 members, ranging from 1 to 8 .

In the native community, comuneros have in average 4 children, while in Santa Maria, the householders have in average 3 children. There are a great percentage of children that have migrated to different places, and Lima, the capital of the country, is the most frequent. Thus $41.4 \%$ of the householders in Laguna-Raya expressed that their children have migrated from the community, and $50.0 \%$ of them expressed that the main reason of migration was to look for a job. In the colonist town $42.9 \%$ of the householders referred that their children have migrated, and for $55.6 \%$ of them the main expressed reason of migration was to look for better education.

Table 7: Mean values-Householder characteristics

\begin{tabular}{|l|r|r|c|c|}
\hline \multicolumn{1}{|c|}{$\begin{array}{c}\text { Origin of } \\
\text { householder }\end{array}$} & Laguna-Raya & Santa María & $\begin{array}{r}\text { P-value } \\
\text { (T-test) }\end{array}$ & $\begin{array}{r}95 \% \\
\text { Confidence } \\
\text { Interval }\end{array}$ \\
\hline Age $(\mathrm{N}=79)$ & $42.4(\mathrm{sd}=13.16)$ \\
$(\mathrm{N}=58)$ & $\begin{array}{r}44.5(\mathrm{sd}=13.03) \\
(\mathrm{N}=21)\end{array}$ & $0.53(\mathrm{~ns})$ & $-8.77 \_4.54$ \\
\hline $\begin{array}{l}\text { Years since settling } \\
(\mathrm{N}=58)\end{array}$ & $20.9(\mathrm{sd}=11.47)$ \\
$(\mathrm{N}=38)$ & $\begin{array}{r}11.4(\mathrm{sd}=6.45) \\
(\mathrm{N}=20)\end{array}$ & $0.001\left(^{*}\right)$ & $3.91 \_15.03$ \\
\hline
\end{tabular}




\begin{tabular}{|l|r|r|r|r|}
\hline Household size $(\mathrm{N}=79)$ & $\begin{array}{r}5.3(\mathrm{sd}=2.22) \\
(\mathrm{N}=58)\end{array}$ & $\begin{array}{r}4(\mathrm{sd}=2.37) \\
(\mathrm{N}=21)\end{array}$ & $0.032\left(^{*}\right)$ & 0.112 .40 \\
\hline $\begin{array}{l}\text { Total number of children } \\
(\mathrm{N}=79)\end{array}$ & $\begin{array}{r}4.3(\mathrm{sd}=2.84) \\
(\mathrm{N}=58)\end{array}$ & $\begin{array}{r}3.4(\mathrm{sd}=2.77) \\
(\mathrm{N}=21)\end{array}$ & $0.25(\mathrm{~ns})$ & $-0.60 \_2.26$ \\
\hline Children migrated $(\mathrm{N}=79)$ & $41.4 \%(\mathrm{~N}=58)$ & $42.9 \%(\mathrm{~N}=21)$ & & \\
\hline
\end{tabular}

* significant differences at $\alpha=0.05$

Thirty-three percent of comuneros in Laguna-Raya have completed primary school as show in Table 8 ; in Santa María only $24 \%$ have completed primary school. In average people from Laguna-Raya have 6.7 years of schooling, while people from Santa María have 4 years of schooling

Table 8: Householder Education $(\mathrm{N}=79)$

\begin{tabular}{|c|c|c|c|c|}
\hline \multirow[t]{2}{*}{ Education } & \multicolumn{2}{|c|}{$\begin{array}{c}\text { Laguna-Raya } \\
(\mathrm{N}=58)\end{array}$} & \multicolumn{2}{|c|}{$\begin{array}{c}\text { Santa María } \\
(\mathrm{N}=21)\end{array}$} \\
\hline & Frea & $\%$ & Freq & $\%$ \\
\hline Illiterate & 7 & 12.07 & 4 & 19.05 \\
\hline Prim.incom & 10 & 17.24 & 9 & 42.86 \\
\hline Prim.comp & 19 & 32.76 & 5 & 23.81 \\
\hline Second.incom & 8 & 13.79 & 3 & 14.29 \\
\hline Second.comp & 8 & 13.79 & & \\
\hline Sup.incom & 3 & 5.17 & & \\
\hline Super.comp & 3 & 5.17 & & \\
\hline
\end{tabular}

Table 9: Mean value-Years of schooling $(\mathrm{N}=79)$

\begin{tabular}{|l|r|r|r|r|}
\hline & Laguna-Raya & Santa María & $\begin{array}{r}\text { P-value } \\
\text { (T-test) }\end{array}$ & $\begin{array}{r}95 \% \\
\text { Confidence } \\
\text { Interval }\end{array}$ \\
\hline $\begin{array}{l}\text { Years of schooling } \\
\text { finished }\end{array}$ & $\begin{array}{r}6.7(\mathrm{sd}=4.25) \\
(\mathrm{N}=58)\end{array}$ & $\begin{array}{r}4(\mathrm{sd}=2.90) \\
(\mathrm{N}=21)\end{array}$ & $0.008\left(^{*}\right)$ & $0.74 \_4.74$ \\
\hline
\end{tabular}

* significant differences at $\alpha=0.05$ 
The main activity among people in both communities is agriculture (Table 10), and it is mainly for subsistence. In Sta María all householders are dedicated to agriculture as their main activity, while in Laguna-Raya only $75.9 \%$ are, because the activities are more diversify

Table 10: Main activity

\begin{tabular}{|l|r|r|r|r|}
\hline \multirow{3}{*}{ Main activity } & \multicolumn{2}{|c|}{$\begin{array}{c}\text { Laguna-Raya } \\
\text { (N=58) }\end{array}$} & \multicolumn{2}{c|}{$\begin{array}{c}\text { Santa María } \\
\text { (N=21) }\end{array}$} \\
\cline { 2 - 5 } & \multicolumn{1}{|c|}{ Freq } & \multicolumn{1}{c|}{$\%$} & Freq & $\%$ \\
\hline Agriculture & 44 & 75.86 & 21 & 100.00 \\
\hline Teacher & 2 & 3.45 & & \\
\hline Commerce & 5 & 8.62 & & \\
\hline Other & 7 & 12.07 & & \\
\hline
\end{tabular}

\section{Land Common property institutions and land tenure}

There are two types of land tenure in the study area: communal and individual land. In Laguna-Raya, there is a unique title for the entire community. In Santa María, where each colonist has an individual land, $90.5 \%$ of the surveyed householders have a secure title, which most of them got just last year, and $9.5 \%$ do not have a title yet because their lands are small portions of settler plots which were sold to later arrivals.

Table 11 shows that average land holdings in Laguna-Raya are 22.7 ha, ranging from 4 to 80 ha. Average land holding in Santa María is 49.3 ha, ranging from 0.03 to 197 ha. 
Table 11: Mean values-Land size $(\mathrm{N}=79)$

\begin{tabular}{|c|c|c|c|c|}
\hline & Laguna-Raya & Santa María & $\begin{array}{l}\text { P-value } \\
\text { (T-test) }\end{array}$ & $\begin{array}{c}95 \% \\
\text { Confidence } \\
\text { Interval }\end{array}$ \\
\hline Land size & $\begin{array}{r}22.7(\mathrm{sd}=16.4) \\
(\mathrm{N}=52)\end{array}$ & $\begin{array}{rr}1) & 49.3(\mathrm{sd}=45.1) \\
(\mathrm{N}=20) & \\
2) & 41.5 \mathrm{sd}=29.6 \\
(\mathrm{~N}=19) & \\
\text { 2. Exclude extreme } \\
\text { values })\end{array}$ & $\begin{array}{l}0.000\left(^{*}\right) \\
0.001\left(^{*}\right)\end{array}$ & $\begin{array}{r}-40.96-12.24 \\
-29.87-7.78\end{array}$ \\
\hline
\end{tabular}

* significant differences at $\alpha=0.05$

\section{Agriculture}

Eighty-eight percent of the comuneros in Laguna-Raya are dedicated in some degree to agriculture, while in Santa María all the householders are dedicated to this activity. Forty-seven percent of farmers in Laguna-Raya produce exclusively for consumption, while 50\% produce for consumption and for market (Table 12). In Santa María 33.3\% of farmers produce exclusively for consumption, while $66.7 \%$ produce for both consumption and market.

Table 12: Purpose of agriculture $(\mathrm{N}=72)$

\begin{tabular}{|l|r|r|r|r|}
\hline & \multicolumn{2}{|c|}{$\begin{array}{c}\text { Laguna-Raya } \\
(\mathbf{N}=\mathbf{5 1})\end{array}$} & \multicolumn{2}{c|}{$\begin{array}{c}\text { Santa María } \\
(\mathbf{N}=\mathbf{2 1})\end{array}$} \\
\cline { 2 - 5 } & Freq & \multicolumn{1}{c|}{$\%$} & \multicolumn{1}{c|}{ Freq } & \multicolumn{1}{c|}{} \\
\hline Excl consumption & 24 & 47.06 & 7 & 33.33 \\
\hline Excl.market & 1 & 1.96 & 0 & 0 \\
\hline Both & 26 & 50.98 & 14 & 66.67 \\
\hline
\end{tabular}

Agricultural land size, which is the land farmers can use for agricultural purposes, averages 9.4 ha among comuneros in Laguna-Raya; in Santa María the average agricultural land size is 17.3 ha. Eighty-eight percent of population in Laguna-Raya 
considered that $1.3 \mathrm{ha} /$ year is the necessary amount to keep a family, while in Santa Maria $76.2 \%$ considered that 2.2 ha is the minimum necessary amount of land for subsistence.

Table 13: Mean values-General agriculture characteristics

\begin{tabular}{|l|r|r|r|r|}
\hline & Laguna-Raya & Santa Maria & $\begin{array}{r}\text { P-value (T- } \\
\text { test) }\end{array}$ & $\begin{array}{c}\text { 95\% } \\
\text { Confidence } \\
\text { Interval }\end{array}$ \\
\hline $\begin{array}{l}\text { Agricultural land size } \\
(\mathrm{Ha})(\mathrm{N}=46)\end{array}$ & $\begin{array}{r}9.4(\mathrm{sd}=6.7) \\
(\mathrm{N}=30)\end{array}$ & $\begin{array}{r}17.3(\mathrm{sd}=14.8) \\
(\mathrm{N}=16)\end{array}$ & $0.02\left(^{*}\right)$ & $-4.24-1.53$ \\
\hline $\begin{array}{l}\text { Distance from home to } \\
\text { chacra (minutes) }(\mathrm{N}=66)\end{array}$ & $48.1(\mathrm{sd}=38.7)$ \\
$(\mathrm{N}=48)$ & $18.2(\mathrm{sd}=19.3)$ \\
$(\mathrm{N}=18)$ & $0.003\left(^{*}\right)$ & 10.71448 .97 \\
\hline $\begin{array}{l}\text { Enough land for annual } \\
\text { family subsistence need } \\
(\mathrm{N}=71)\end{array}$ & $88 \%(\mathrm{~N}=50)$ & $76.2 \%(\mathrm{~N}=21)$ & \\
\hline $\begin{array}{l}\text { Ha/year needed for } \\
\text { keeping family }(\mathrm{N}=65)\end{array}$ & $1.3(\mathrm{sd}=0.73)$ \\
$(\mathrm{N}=45)$ & $2.2(\mathrm{sd}=1.6)$ \\
$(\mathrm{N}=20)$ & $0.002\left(^{*}\right)$ & \\
\hline
\end{tabular}

* significant differences at $\alpha=0.05$

There are few problems with pests in both communities, although $60 \%$ of people in Laguna-Raya reported that some crops in riparian zones and uplands are affected by some insects, while in Santa María $72 \%$ of people reported this. There is no a real use of insecticides because there is not enough money to buy them, but the four people who use them in Laguna-Raya used parathion and furadan, which are very toxic insecticides. Only one person in Laguna-Raya reported to use mechanical methods (take out infected leaves or clean the area of weeds). In Santa María just one person uses barbasco as an insecticide against worms in corn and beans in a mixture of $1 / 2$ cup of barbasco to 15 liters of water. 
The main crops affected by insects or diseases are coffee (broca de café, arañera, ojo de pollo), plantain (worms, root rot), manioc (root rot, ants, paca), beans (worms, crickets, gorgojos), palm heart (weevil and rodents), corn (worms, weevil), and peanut (weevil).

\section{Agriculture in Uplands}

In Laguna-Raya $80.4 \%$ of the farmers cultivate in uplands, and $76.2 \%$ do this in Santa María (Table 14). Land size under use in uplands averages 2.0 ha in Laguna-Raya, ranging from 0.5 to $7 \mathrm{ha}$, and 1.5 ha in Santa Maria, ranging from 0.03 to 3.5 ha. The general system of cultivation in uplands is that farmers cut an area, sow it and after an average of 1.5 years, in the case of the native sector, they move to another area, having a rotation period of 4 years. In Santa María 1.4 years is the average time farmers use a plot, leaving this in fallow during 3 years.

Table 14: Mean values-Agriculture in uplands

\begin{tabular}{|c|c|c|c|c|}
\hline & Laguna-Raya & Santa María & $\begin{array}{l}\text { P-value } \\
\text { (T-test) }\end{array}$ & $\begin{array}{c}95 \% \\
\text { Confidence } \\
\text { Interval }\end{array}$ \\
\hline $\begin{array}{l}\text { Cultivate in uplands } \\
(\mathrm{N}=72)\end{array}$ & $80.4 \%(\mathrm{~N}=51)$ & $76.2 \%(\mathrm{~N}=21)$ & 0.58 (ns) & $-0.15 \quad 0.27$ \\
\hline $\begin{array}{l}\text { Area in uplands under } \\
\text { use }(\mathrm{Ha})(\mathrm{N}=54)\end{array}$ & $\begin{array}{r}2.0(\mathrm{sd}=1.5) \\
(\mathrm{N}=38)\end{array}$ & $\begin{array}{r}1.5(\mathrm{sd}=1.0) \\
(\mathrm{N}=16) \\
\end{array}$ & 0.19 (ns) & $-0.27 \_1.34$ \\
\hline $\begin{array}{l}\text { Years chacra in the } \\
\text { same place }(N=71)\end{array}$ & $\begin{array}{r}1.5(\mathrm{sd}=1.2) \\
(\mathrm{N}=50)\end{array}$ & 1) $\begin{array}{r}1.43(\mathrm{sd}=1.5) \\
(\mathrm{N}=21) \\
2) \quad 1.1(\mathrm{sd}=0.3) \\
\mathrm{N}=20\end{array}$ & $\begin{array}{l}0.79(\mathrm{~ns}) \\
0.126(\mathrm{~ns})\end{array}$ & $\begin{array}{r}-0.58 \quad 0.77 \\
0.06 \quad 0.78\left(^{*}\right)\end{array}$ \\
\hline $\begin{array}{l}\text { Rotation period } \\
(\mathrm{N}=50)\end{array}$ & $\begin{array}{r}\text { 1) } 3.7(\mathrm{sd}=3.3) \\
(\mathrm{N}=33) \\
2) 3.2(\mathrm{sd}=1.5) \\
(\mathrm{N}=32) \\
\text { (2. exclude one } \\
\text { extreme value })\end{array}$ & $\begin{array}{r}2.9(\mathrm{sd}=1.4) \\
(\mathrm{N}=17)\end{array}$ & $\begin{array}{l}0.26(\mathrm{~ns}) \\
0.56(\mathrm{~ns})\end{array}$ & $\begin{array}{l}-0.91 \_2.42 \\
-0.62 \_1.11\end{array}$ \\
\hline
\end{tabular}




\begin{tabular}{|l|r|r|r|l|}
\hline $\begin{array}{l}\text { Production decreases } \\
\text { with time }(\mathrm{N}=72)\end{array}$ & $31.4 \%(\mathrm{~N}=51)$ & $33.3 \%(\mathrm{~N}=21)$ & & \\
\hline
\end{tabular}

* significant differences at $\alpha=0.05$

Table 15 shows that the main crops sowed in uplands are manioc and plantain in both communities. In Laguna-Raya $95.1 \%$ of people grow manioc in this area, while $75 \%$ do this in Santa María. In Santa Maria $93.8 \%$ of people grow plantain in uplands while only $56.1 \%$ do this in Laguna-Raya. Other crops sowed in uplands are pituca, citrics, and coffee $(41.5 \%)$ as the main cash crop.

Table 15: Crops in Uplands $(\mathrm{N}=57)$

\begin{tabular}{|c|c|c|c|c|c|c|}
\hline \multirow[t]{2}{*}{ Crops } & \multicolumn{2}{|c|}{ Raya $(N=41)$} & \multicolumn{2}{|c|}{ Sta María $(\mathrm{N}=16)$} & \multirow{2}{*}{$\begin{array}{l}\text { P-value } \\
\text { (T-test) }\end{array}$} & \multirow{2}{*}{$\begin{array}{c}95 \% \\
\text { Confidence } \\
\text { Interval }\end{array}$} \\
\hline & $\begin{array}{c}\text { Producers } \\
\#\end{array}$ & $\begin{array}{c}\text { Producers } \\
\%\end{array}$ & $\begin{array}{c}\text { Producers } \\
\#\end{array}$ & $\begin{array}{c}\text { Producers } \\
\%\end{array}$ & & \\
\hline Plantain & 23 & 56.1 & 15 & 93.8 & $0.006\left(^{*}\right)$ & $-0.64-0.11$ \\
\hline Manioc & 39 & 95.1 & 12 & 75.0 & $0.026(*)$ & 0.020 .38 \\
\hline Pituca & 17 & 41.5 & 7 & 43.8 & 0.878 (ns) & -0.320 .27 \\
\hline Coffee & 17 & 41.5 & 8 & 50.0 & $0.568(\mathrm{~ns})$ & -0.380 .21 \\
\hline Citrus & 1 & 2.4 & 2 & 12.5 & $0.131(\mathrm{~ns})$ & -0.230 .03 \\
\hline Other & 8 & 19.5 & 3 & 18.8 & 0.949 (ns) & $-0.23 \quad 0.24$ \\
\hline
\end{tabular}

* significant differences at $\alpha=0.05$

\section{Agriculture in Riparian zones}

In Laguna-Raya $55.2 \%$ of the comuneros had access to riparian zones at the moment of the interview (Table 16 ), and 10 people $(31.3 \%)$ were using communal riparian zones. All comuneros with access to riparian zones use them for agricultural purposes, just one person in Laguna-Raya does not use it, because he is dedicated to 
commercial activities. In Santa María $76.2 \%$ of colonists have access to riparian zones, and all them use these areas for agricultural purposes.

Table 16: Number of people with access to riparian zones $(\mathrm{RZs})(\mathrm{N}=49)$

\begin{tabular}{|l|r|r|r|r|r|c|}
\hline & \multicolumn{2}{|c|}{$\begin{array}{c}\text { Laguna-Raya } \\
(\mathbf{N}=\mathbf{3 3})\end{array}$} & \multicolumn{2}{|c|}{$\begin{array}{c}\text { Santa María } \\
(\mathbf{N = 1 6})\end{array}$} & \multirow{2}{*}{$\begin{array}{c}\text { P-value } \\
\text { (T-test) }\end{array}$} & $\begin{array}{c}\text { 95\% } \\
\text { Confidence } \\
\text { Interval }\end{array}$ \\
\cline { 2 - 5 } & Freq & \multicolumn{1}{c|}{$\%$} & \multicolumn{1}{|c|}{ Freq } & \multicolumn{1}{c|}{$\%$} & & \\
\hline $\begin{array}{l}\text { \# people with access to } \\
\text { RZs }\end{array}$ & 33 & 56.90 & 16 & 76.2 & & \\
\hline $\begin{array}{l}\text { \# people using RZs } \\
\text { (N=48) }\end{array}$ & 32 & 96.2 & 16 & 100.00 & $0.09(\mathrm{~ns})$ & $-0.45 \_0.04$ \\
\hline
\end{tabular}

* significant differences at $\alpha=0.05$

People with access to riparian zones at their arrival to their respective community found these areas with abundant vegetation, $93.9 \%$ of people in Laguna-Raya, and $87.5 \%$ of colonists in Santa María (Table 17). Most people, $78.8 \%$ in Laguna-Raya and $68.8 \%$ in Santa María, left riparian vegetation for protection of their lands (Table 18).

Table 17: Situation of riparian zones at arrival to the community $(N=49)$

\begin{tabular}{|l|r|r|r|r|}
\hline & \multicolumn{2}{|c|}{$\begin{array}{c}\text { Laguna-Raya } \\
(\mathbf{N}=33)\end{array}$} & \multicolumn{2}{c|}{$\begin{array}{c}\text { Santa María } \\
(\mathbf{N = 1 6 )}\end{array}$} \\
\cline { 2 - 5 } & \multicolumn{1}{|c|}{ Freq } & \multicolumn{1}{c|}{$\%$} & \multicolumn{1}{c|}{ Freq } & \multicolumn{1}{c|}{$\%$} \\
\hline abundant forest & 31 & 93.9 & 14 & 87.5 \\
\hline some forest & 0 & 0 & 1 & 6.3 \\
\hline nothing forest & 2 & 6.1 & 1 & 6.3 \\
\hline
\end{tabular}

Table 18: Treatment of riparian vegetation at arrival to the community $(\mathrm{N}=49)$

\begin{tabular}{|l|r|r|r|r|}
\hline \multirow{2}{*}{} & \multicolumn{2}{|c|}{$\begin{array}{c}\text { Laguna-Raya } \\
(\mathbf{N}=33)\end{array}$} & \multicolumn{2}{c|}{$\begin{array}{c}\text { Santa María } \\
(\mathbf{N}=16)\end{array}$} \\
\cline { 2 - 5 } & \multicolumn{1}{|c|}{ Freq } & \multicolumn{1}{c|}{$\%$} & \multicolumn{1}{c|}{ Freq } & \multicolumn{1}{c|}{$\%$} \\
\hline left it for protect & 26 & 78.8 & 11 & 68.8 \\
\hline cut part of it & 5 & 15.2 & 3 & 188 \\
\hline other & 2 & 6.1 & 2 & 12.5 \\
\hline
\end{tabular}


Comuneros in Laguna-Raya have an average length of river in their properties of 315 meters, while in Santa María, the average length was almost double (656 meters).

Table 19 shows that in both communities a great percentage of people, $87.9 \%$ in Laguna-Raya and $75 \%$ in Santa Maria, leave a fringe of trees as protection of their lands in riparian zones. This fringe is not so variable between these two communities, the mean is 22.1 meters in Laguna-Raya and 27.5 meters in Santa Maria.

A big percentage of the protection fringe is forested in both communities In Laguna-Raya this percentage is in average $99 \%$, while in Santa Maria it is $82 \%$. The area of riparian zone under use among comuneros in the native community is in average 1.1 ha, ranging from 0.2 to 3 ha. For colonists in Santa María the area under use is 1.8 ha in average, ranging from 0.2 to 5.7 ha.

Table 19: Mean values and percentages-Riparian zones characteristics

\begin{tabular}{|c|c|c|c|c|}
\hline & Laguna-Raya & Santa María & $\begin{array}{l}\text { P-value } \\
\text { (T-test) }\end{array}$ & $\begin{array}{c}95 \% \\
\text { Confidence } \\
\text { Interval }\end{array}$ \\
\hline $\begin{array}{l}\text { Lenght of river } \\
\text { in property } \\
\text { (meters) }(\mathrm{N}=46)\end{array}$ & $\begin{array}{r}315.2(\mathrm{sd}=278.9) \\
(\mathrm{N}=31)\end{array}$ & $\begin{array}{rr}\text { 1) } 656.3(\mathrm{sd}=698.4) \\
(\mathrm{N}=15) \\
2) \quad 488.9(\mathrm{sd}=269.5) \\
\mathrm{N}=14 \\
\\
\text { (2. Exclude one extreme } \\
\text { value }) \\
\end{array}$ & $\begin{array}{l}0.02\left({ }^{*}\right) \\
0.06(\mathrm{~ns})\end{array}$ & $\begin{array}{r}-630.42-51.93 \\
-354.086 .54\end{array}$ \\
\hline $\begin{array}{l}\text { \# people leave a } \\
\text { protection fringe } \\
\text { in } R Z(N=49)\end{array}$ & $29(87.9 \%)(\mathrm{N}=33)$ & $12(75.0 \%)(\mathrm{N}=16)$ & & \\
\hline $\begin{array}{l}\text { Meters of } \\
\text { protection fringe } \\
\text { in } R Z(N=41)\end{array}$ & $\begin{array}{rr}\text { 1) } & 22.1(\mathrm{sd}=21.5) \\
& (\mathrm{N}=29) \\
2) & 19.3(\mathrm{sd}=15.7) \\
(\mathrm{N}=28) \\
\\
\text { (2. Exclude one extreme } \\
\text { value) } \\
\text { rer }\end{array}$ & $\begin{array}{r}27.5(\mathrm{sd}=27.3) \\
(\mathrm{N}=12)\end{array}$ & $\begin{array}{l}0.50 \text { (ns) } \\
0.24 \text { (ns) }\end{array}$ & $\begin{array}{r}-21.55 \_10.76 \\
-21.97 \_5.62\end{array}$ \\
\hline
\end{tabular}




\begin{tabular}{|l|r|r|r|r|}
\hline $\begin{array}{l}\text { \% of protection } \\
\text { fringe in } \mathrm{RZ} \text { that } \\
\text { is forested } \\
(\mathrm{N}=42)\end{array}$ & $99(\mathrm{sd}=3.1)(\mathrm{N}=30)$ & $82.5(\mathrm{sd}=24.5)(\mathrm{N}=12)$ & $0.001\left(^{*}\right)$ & $7.44 \_25.56$ \\
\hline $\begin{array}{l}\text { Area of } \mathrm{RZ} \\
\text { under use (ha) } \\
(\mathrm{N}=45)\end{array}$ & $1.1(\mathrm{sd}=0.79)$ \\
$(\mathrm{N}=30)$ & $1.9(\mathrm{sd}=1.5)$ \\
$(\mathrm{N}=15)$ & $0.04\left(^{*}\right)$ & $-1.42-0.04$ \\
\hline
\end{tabular}

* significant differences at $\alpha=0.05$

Riparian zones are sowed once per year, and the most frequent crops sowed by comuneros from Laguna-Raya are corn, peanuts, beans, manioc, plantains, and pituca, but corn, and plantains are the most grown. Table 20 shows the percentages of producers of these crops. For the colonists from Santa María, typical crops grown in riparian zones are corn, manioc, and plantains. Even though coffee is not a crop for riparian zones, one person in Santa Maria is growing it in these areas.

Table 20: Principal crops in riparian zones $(\mathrm{N}=48)$

\begin{tabular}{|c|c|c|c|c|c|c|}
\hline \multirow[t]{2}{*}{ Crops } & \multicolumn{2}{|c|}{ Raya (N=41) } & \multicolumn{2}{|c|}{ Sta Maria $(N=16)$} & \multirow{2}{*}{$\begin{array}{l}\text { P-value } \\
\text { (T-test) }\end{array}$} & \multirow{2}{*}{$\begin{array}{c}95 \% \\
\text { Confidence } \\
\text { Interval }\end{array}$} \\
\hline & Producers \# & $\begin{array}{l}\text { Producers } \\
\%\end{array}$ & Producers \# & $\begin{array}{l}\text { Producers } \\
\%\end{array}$ & & \\
\hline Corn & 23 & 71.9 & 9 & 56.3 & 0.289 (ns) & -0.140 .45 \\
\hline Peanut & 15 & 46.9 & 1 & 6.3 & $0.004\left(^{*}\right)$ & $0.14 \quad 0.68$ \\
\hline Bean & 13 & 40.6 & 1 & 6.3 & $0.013\left(^{*}\right)$ & $0.08 \quad 0.61$ \\
\hline Manioc & 17 & 53.1 & 9 & 56.3 & 0.842 (ns) & -0.340 .28 \\
\hline Plantain & 24 & 75.0 & 8 & 50.0 & 0.087 (ns) & -0.040 .54 \\
\hline Pituca & 7 & 21.9 & 3 & 18.8 & 0.807 (ns) & $-0.22 \quad 0.29$ \\
\hline Citrus & 1 & 3.1 & 2 & 12.5 & 0.214 (ns) & -0.240 .06 \\
\hline Rice & 1 & 3.1 & 3 & 18.8 & 0.067 (ns) & -0.320 .01 \\
\hline Coffee & 0 & 0 & 1 & 6.3 & 0.160 (ns) & $-0.15 \quad 0.03$ \\
\hline Other & 6 & 18.8 & 6 & 37.5 & 0.164 (ns) & -0.450 .08 \\
\hline
\end{tabular}

* significant differences at $\alpha=0.05$ 
Thirty-nine percent of respondents in Laguna-Raya said that the main reason for sowing these crops in riparian zones was because these crops grow better there (Table 21). For $37.5 \%$ of respondents in Santa María, the main reason of sowing these crops in riparian zones was fertility of soils. The high fertility of these areas induces farmers to plant crops of short growing season there; crops that mature in three or four months.

Table 21: Principal reason to plant some crops in Riparian zones $(N=49)$

\begin{tabular}{|l|r|r|r|r|}
\hline \multirow{2}{*}{} & \multicolumn{2}{|c|}{$\begin{array}{c}\text { Laguna-Raya } \\
(\mathbf{N}=33)\end{array}$} & \multicolumn{2}{c|}{$\begin{array}{c}\text { Santa María } \\
(\mathbf{N}=16)\end{array}$} \\
\cline { 2 - 5 } & \multicolumn{1}{|c|}{ Freq } & \multicolumn{1}{c|}{$\%$} & \multicolumn{1}{c|}{ Freq } & \multicolumn{1}{c|}{$\%$} \\
\hline Fertile soils & 12 & 36.4 & 6 & 37.5 \\
\hline Better grow here & 13 & 39.4 & 2 & 12.5 \\
\hline other & 7 & 21.2 & $\mathbf{8}$ & 50.0 \\
\hline
\end{tabular}

All the interviewed comuneros in Laguna-Raya answered that riparian zones are important because of soil protection $(60.6 \%)$, soil fertility $(30.3 \%)$, existence of more flora and fauna (6.1\%), and esthetics (3.0\%) (Table 22, 23). For the colonists, $81.2 \%$ consider that riparian zones are important for protection of soil $(62.5 \%)$ and soil fertility (18.8\%); however $18.8 \%$ of those interviewed said that these areas are not important, by the contrary, they are a risk for their crops and property.

Table 22: Number of people for whom riparian zones are important $(\mathrm{N}=49)$

\begin{tabular}{|l|r|r|r|r|}
\hline & $\begin{array}{c}\text { Laguna-Raya (\%) } \\
(\mathbf{N}=33)\end{array}$ & $\begin{array}{c}\text { Santa Marí (\%) } \\
(\mathbf{N}=16)\end{array}$ & $\begin{array}{c}\text { P-value } \\
(\text { T-test })\end{array}$ & $\begin{array}{c}95 \% \\
\text { Confidence } \\
\text { Interval }\end{array}$ \\
\hline $\begin{array}{l}\text { Riparian zones } \\
\text { importance }\end{array}$ & 100 & 81.3 & $0.01\left(^{*}\right)$ & 0.050 .33 \\
\hline
\end{tabular}

* significant differences at $\alpha=0.05$ 
Table 23: Reasons why riparian zones are important $(\mathrm{N}=49)$

\begin{tabular}{|c|c|c|c|c|}
\hline & \multicolumn{2}{|c|}{$\begin{array}{l}\text { Laguna-Raya } \\
(\mathrm{N}=33)\end{array}$} & \multicolumn{2}{|c|}{$\begin{array}{c}\text { Santa María } \\
(\mathrm{N}=16)\end{array}$} \\
\hline & Freq & $\%$ & Frea & $\%$ \\
\hline Protection & 20 & 60.6 & 10 & 62.5 \\
\hline Fertile soil & 10 & 30.3 & 3 & 18.8 \\
\hline Fauna \& life & 2 & 6.1 & 0 & 0 \\
\hline Esthetic & 1 & 3.0 & 0 & 0 \\
\hline No important & 0 & $\frac{\pi}{0}$ & 3 & 18.8 \\
\hline
\end{tabular}

Few people in both communities have reforested riparian zones. In Laguna-Raya $29.4 \%$ reforested these areas, while in Santa María only $6.3 \%$ did it.

Table 24: People who has reforested riparian zones

\begin{tabular}{|l|c|c|c|c|}
\hline & $\begin{array}{c}\text { Laguna-Raya (\%) } \\
(\mathbf{N}=34)\end{array}$ & $\begin{array}{c}\text { Santa María (\%) } \\
(\mathbf{N}=16)\end{array}$ & $\begin{array}{c}\text { P-value } \\
\text { (T-test) }\end{array}$ & $\begin{array}{c}95 \% \\
\text { Confidence } \\
\text { Interval }\end{array}$ \\
\hline \# People & $10(29.4 \%)$ & $1(6.3 \%)$ & $0.07(\mathrm{~ns})$ & $-0.02 \_0.48$ \\
\hline
\end{tabular}

People with access to riparian zones do not show significant differences with respect to people that do not have access to them (Table 25).

Table 25: How do people who use riparian zones differ from others in the community?

\begin{tabular}{|l|r|r|}
\hline & \multicolumn{1}{|c|}{ P-value (T-test) } & 95\% Confidence Interval \\
\hline Age & $0.726(\mathrm{~ns})$ & $-9.01 \_6.32$ \\
\hline Years living in place & $0.015\left(^{*}\right)$ & $1.91 \_16.7$ \\
\hline Land size & $0.001\left(^{*}\right)$ & $-48.68 \_-12.9$ \\
\hline Household size & $0.03\left(^{*}\right)$ & $0.84 \_3.72$ \\
\hline Total number children & $0.079\left(^{*}\right)$ & -0.1933 .38 \\
\hline Agricultural land size & $0.020\left(^{*}\right)$ & $-13.63 \_-1.24$ \\
\hline Years chacra in the same place & $0.186(\mathrm{~ns})$ & $-0.21 \_1.05$ \\
\hline Rotation period & $0.331(\mathrm{~ns})$ & $-1.04 \_3.01$ \\
\hline Ha per year for keeping family & $0.022\left(^{*}\right)$ & $-1.53 \_-0.13$ \\
\hline
\end{tabular}


Considering $50 \mathrm{~m}$ as the ideal width that householders should leave in the protection fringe along riparian zones, more people in Santa María are closer to the ideal protection fringe than people in Laguna-Raya.

1. Real Area Protection Fringe $=$ Meters of protection $x$ Length of river in property

2. Ideal Area Protection Fringe $=50 \mathrm{~m} \times$ Length of river in property

3. $\%$ of Ideal Protection Fringe $=($ Real Prot. Fringe $/$ Ideal Prot. Fringe $) * 100$

Table 26: Pearson correlation-Ideal protection fringe

\begin{tabular}{|l|r|r|}
\hline \multicolumn{1}{|c|}{ Location } & Ideal Protection Fringe & \multicolumn{2}{c|}{$\begin{array}{c}\text { Ideal Protection } \\
\text { Fringe }\end{array}$} \\
\hline Pearson correlation & $-0.337^{*}$ & -0.191 \\
\hline $\mathrm{P}$-value & 0.022 & 0.245 \\
\hline $\mathrm{N}$ & 46 & 39 \\
\hline
\end{tabular}

\section{Livestock}

Livestock is the second economic activity for both subsistence and income in both communities. In Laguna-Raya $79 \%$ of the population has developed the raising of small livestock, while in Santa María $95.2 \%$ of colonist are involved in the raising of small livestock. Tables 27 and 28 indicate that almost all in Laguna-Raya (98\%) and in Santa María (100\%) have chicken, and some people in Laguna-Raya (15.6\%) are raising pigs as a way to get income, because their religion does not allow them to eat pork. 
Table 27: Distribution of small livestock in Laguna-Raya ( $N=46)$

\begin{tabular}{|l|c|c|c|c|}
\hline & Chicken & Duck & Turkey & Pig \\
\hline \# Producers & 45 & 6 & 3 & 7 \\
\hline \% Producers & 97.8 & 13.3 & 6.7 & 15.6 \\
\hline
\end{tabular}

Table 28: Distribution of small livestock in Santa María $(\mathrm{N}=20)$

\begin{tabular}{|l|c|c|c|c|c|}
\hline & Chicken & Duck & Turckey & Pig & Cuy \\
\hline \# Producers & 20 & 7 & 2 & 6 & 4 \\
\hline \% Producers & 100.0 & 35.0 & 10.0 & 30.0 & 20.0 \\
\hline
\end{tabular}

Twelve people in Laguna-Raya possess cattle (20.7\%), while in Santa María just one person has cattle. The local breed is a mixture of Brown Swiss with cebu. Ninety-two percent of people in Laguna-Raya sow pasture for raising cattle, with brizante, cutzu, and maicillo pastures being preferred. In Santa María the only person raising cattle also sowes pasture. Two people in Laguna-Raya have sheep (3.5\%).

More than half of comuneros $(58.3 \%)$ who have cattle said that they raise them exclusively to sell. In Santa María the only rancher grows cattle for consumption and sell to Villa Rica market. Sixty-seven percent of householders in Laguna-Raya reported diseases in their cattle, such as rabies, carbuncle, cattle tick, worms, and fiebre aftosa; similar diseases were mentioned for the rancher in Santa María. Forty-two percent of the comuneros whose cattle is affected for some of these diseases use some form of control, with some of them applying a vaccine ( $3 \mathrm{cc} / \mathrm{head})$ once per year. Others use repercol for parasites, and megazona for worms. The rancher form Santa María control these diseases vaccinating his cattle twice per year. 


\section{Hunting}

As showed in Table 29 and 30, the most frequently hunted species in LagunaRaya are paca (Agouti paca), doves (Columbidae), tinamous (Tinamus spp.), agouti (Dasyprocta sp.), and deer (Mazama americana), and in Santa Maria paca is the main game hunted. Fifty-four percent of people in Laguna-Raya hunt, and in Santa Maria 52\%. In Laguna-Raya this activity is carried out mainly for consumption (61.3\%), and formerly people hunted one to two times per month (38.7\%). In Santa María From the hunter population $36.4 \%$ hunt once or twice per year, and $36.4 \%$ do this twice to three times per year. Most of the people in both communities hunt significantly more during MaySeptember, $74.2 \%$ in Laguna-Raya and $72.7 \%$ in Santa María, than during DecemberFebruary. Principal places for hunting in Laguna-Raya are primary forest $(45.2 \%)$, chacra $(29.0 \%)$, and both $(25.8 \%)$. In Santa María hunting is done in primary forests $(36.4 \%)$, chacras $(45.5 \%)$, creeks $(9.1 \%)$, and in primary forests as well as in chacras $(9.1 \%)$.

Table 29: Principal animals hunted in Laguna-Raya $(\mathrm{N}=31)$

\begin{tabular}{|l|c|c|c|c|c|c|c|}
\hline & $\begin{array}{c}\text { Collared } \\
\text { peccary }\end{array}$ & Paca & Deer & Agouti & Armadillo & Birds & Others \\
\hline \# Huntings & 5 & 22 & 6 & 7 & 4 & 18 & 6 \\
\hline$\%$ Huntings & 16.13 & 70.97 & 19.35 & 22.58 & 12.90 & 58.06 & 19.35 \\
\hline
\end{tabular}

Table 30: Principal animals hunted in Santa Maria $(\mathrm{N}=11)$

\begin{tabular}{|l|c|c|c|c|c|c|}
\hline & $\begin{array}{c}\text { Collared } \\
\text { peccary }\end{array}$ & Paca & Deer & Agouti & Birds & Others \\
\hline \# Hunting & 4 & 11 & 1 & 1 & 2 & 1 \\
\hline$\%$ Hunting & 36.4 & 100.0 & 9.1 & 9.1 & 18.2 & 9.1 \\
\hline
\end{tabular}




\section{Fishing}

Constitutes the third most important economic activity for subsistence in both communities. In Laguna-Raya $85 \%$ of people practice this activity and $40.8 \%$ of them do this once per week. In Santa Maria all the people practice this activity mainly once per week (33.33\%). The most used fishing tools in Laguna-Raya are hook-line (77.6\%) and cast-net (77.6\%); also some people fish by hand (32.7\%), and others use arrows (12.2\%). In Santa María the most used fishing methods are hook-line (81.0\%), and cast-net (76.2\%). Thirty-nine percent of people in Laguna-Raya use small amounts of barbasco or huaco (natural poison for killing fish). Although all the people in Santa María denied the use of poisons for fishing, some colonists reported that natives from the town or from close towns use them in the river. On average weight per captured fish is $2.24 \mathrm{Kg}$ in Laguna-Raya, and $2.05 \mathrm{Kg}$ in Santa María. In Laguna-Raya carachama (Pterygoplichthys multiradiatus) is the most abundant and consumed species, followed by chupadora or boquichico (Prochilodus nigricans), sabalo (Brycon sp.), and corvina (Salminus affinis). In Santa María the main fish caught are corvina (Salminus affinis), carachama (Pterygoplichthys multiradiatus), and sabalo (Brycon sp.); other species are chupadora (Prochilodus nigricans), barbon, sungaro, doncella, and anchoveta. Fish is consumed in greater quantities in the summer because this is the main season for this activity.

\section{Gathering}

Forty-seven percent of people in Laguna-Raya collect a large variety of plant parts, wood, and fruits mainly for subsistence, while in Santa Maria $52 \%$ of people collect products from the forest. Fifty-two percent of people in Laguna-Raya collect fruits 
such as pama which is harvested between August and September, caimito is harvested from April to June, and almonds between April and May.

Medicinal plants are collected by $55.6 \%$ of the population in Laguna-Raya mainly from primary forest $(92.6 \%)$. Some in Laguna-Raya (29.6\%) are dedicated to sell timber from Loma Linda and Raya. This activity is done mainly during winter, and the most common marketed tree species are tornillo (Cedrelinga catenaeformis) and palos corrientes. Timber is generally sold by contract, so the traders buy trees, saw them in the forest, and the buyers pick the wood up on the road. One of the comuneros dedicated to this activity reported buying wood close to the road at S/0.20/board feet, and selling it after sawing at $\mathrm{S} / .0 .70 /$ board feet for tornillo and $\mathrm{S} / 0.40 /$ board feet for corrientes.

In Sta María 36\% of people collect some fruits such as pama in September and wild lucuma in February. Medicinal plants are collected by $90.9 \%$ of the population in primary forest and only for personal use. 


\section{DISCUSSION}

Since the objective of my study is to determine land use of riparian zones in two communities, my discussions are based in agricultural aspects, as the main activity carried out in riparian zones.

\section{Household characteristics}

The two studied communities, Laguna-Raya and Santa Maria, are socially mixed as show in Table 6. However they are still characterized as native and colonist on the basis of land tenure. Even though most of the literature points out differences in behavior between colonists and natives, people from Laguna-Raya do not present that much differences. As Browder (1995) points out some colonists because of the interaction through time with their environment increase their knowledge about tropical environments and preserve it as natives do. In Laguna-Raya, colonists who were incorporated to the community behave as natives, because from the moment they were accepted to be part of the community and they became comuneros, they had to follow communal rules established for all the comuneros without distinctions.

Population in both communities is relatively young and there are not significant differences between them (Table 7). However significant differences were found between the number of years since settling in both communitites. In Laguna-Raya it is almost the double that in Santa Maria. The explanation is that most of the migration into the Loma Linda-Laguna native community occurred by the 1970 s, while in Santa María just one colonist arrived by the 1970 s and the majority arrived in the 1980 s with the opening of the Marginal road. 
There are significant differences in the number of members in both communities. The high number of members per family is a common denominator in remote areas such as my study area, because of the necessity for more hands in agricultural labors. Despite differences in the number of members per family no significant differences between the number of children in these communities were found.

The existence of only one secondary school in Raya, two hours far from Santa María by walking, made it difficult for children in this community to continue their studies there; that is one of the reasons why a high percentage of children left Santa María.

Supposedly, colonists have a higher level of education than natives because of more income and easier access to education in cities. However in my study population the level of education was higher among the comuneros in the native community (Laguna-Raya). Significant differences also occur in the number of schooling years as shown in Table 9. Most of the colonists who arrived in Santa María were people with a low level of education in search of land. In the case of Laguna-Raya, most of the people who migrated to the community, Yaneshas or colonists, lived close to cities before, so they received at least a primary education there. Most of the Yanesha communities have a high index of literacy, and according to Brack (1987) at least $75 \%$ of the Yanesha population has primary education.

Agriculture is the main activity for people in both communities, however activities are more diversify in Laguna-Raya where some people have temporary jobs such as agricultural labors in chacras of others, cattle raising activities on colonist ranches located close to the community, building, and saw mills. Others have more permanent 
jobs such as workman for the PEPP and Pronaturaleza, merchants, and teachers in the school.

\section{Land tenure}

The entire Loma Linda-Laguna community, when it was named as a Native Community, received a fixed amount of land which was distributed among the male members of the community through an internal agreement among them (General Assembly). Comuneros who arrived first to the community received more lands, an average of 30 ha for agricultural purposes and 60 ha for pasture. Table 11 shows that today average land holding in Laguna-Raya is below of what was established by General Assembly, mainly because of population growth, so people who arrived later to the community received less lands because of the less availability of them. In Santa Maria, the first colonists who arrived in the area took the land they wanted, and as part of the colonization process after some years working these lands they claimed them to the Agricultural Ministery. Here people who arrived first found more available lands, so they had the possibility to claim larger homesteads. Today the average land holding in Santa María is 49.3 ha. Because just one person has a big amount of land, which skews the community statistics, I decided to consider this value (197) as an outlier. However after the statistical test was applied (T-test) no statistical changes occurred, and still significant differences were found between the amount of land possesed in the native and colonist community.

The only available classification of land use patterns in the Loma Linda-Laguna community was elaborated in 1982 and shows that: 
- $84 \%$ are lands for forest and protection; these are high hills, creeks with pronounced slope, and mountains.

- $\quad 9 \%$ are lands for permanent crops; usually on terraces above riparian zones, where coffee is cultivated through an agroforestal system (Coffea-Inga-Cedrelinga) with Leguminoseae and green manure as Centrosema sp., and Arachis sp. "mani forrajero".

- $\quad 7 \%$ are lands for annual crops; lands along the edges of the Raya and Palcazu rivers. They are from low to medium height terraces, with flat topography, short hillside, sandy and deep soils, with $\mathrm{pH}$ of 5.2-6.2, good and fast drainage, and high content of organic material.They are used for cultivating exigent crops such as corn, peanut, bean, and watermelon. Thus agricultural land in riparian zones in Laguna-Raya is quite limited. My research suggests that the area for this purpose is 217 ha.

- $\quad 0 \%$ are lands for pasture. My research does not permit a complete updating of land use in the Laguna-Raya community, but 243 ha today are used in cattle pasture.

\section{Agriculture}

Land use systems practiced by small farmers in the study areas involve the traditional farming patterns of the Yanesha and the adoption of local farming patterns and the adaptation of their own past experiences in the case of the colonists in the colonist community. The majority of householders practice some form of polyculture. Now farmers have fields in uplands and in riparian zones, and agricultural practices and crop choices differ between these two land types. Upland soils are infertile and when exposed are susceptible to leaching and erosion. Riparian zones, because of the input of nutrients 
carried by water, can be used for production of more nutrient demanding crops. Rejuvenation of riparian zone soils permits much higher yields than is typically achieved on upland sites. As Smith (1982) refers crop production in upland areas is limited by many problems, because soils are generally too poor for sustained annual cropping without fertilizers and weed control, and also many sites are steep and prone to soil erosion in contrast to the relatively flat riparian zones.

Farmers plant annuals, such as corn, peanuts and beans (in riparian zones), semiperennials such as plantains and manioc, and some farmers plant some perennials such as coffee, citrus, and cacao.

In Laguna-Raya and in general in the Palcazu valley, Yanesha agriculture is for subsistence. It is restricted by the lack of land in floodplains and thus depends on the use of abundant lands but poorer upland soils. Because of the high precipitation in LagunaRaya, it is rare that fields are burned very well, and frequently unburned residues are removed from the field or left as mulch (Salick, 1986). Smith (1982) notes that Yanesha household members plant up to three separate gardens each year: 1) one, often less than $1 / 4$ ha, is planted with beans; 2) a second one, up to one ha on the more fertile lands (riparian zones) is planted with corn, banana, peanut, and taro; and 3) a third one, often one or two ha in the less fertile lands (uplands) is planted with manioc. The smaller field may have disappeared from use, since informants in Laguna-Raya did not report it.

According to Boulan (1999) each agricultural year consists of two four-month cycles. The first cycle begins in February with the sowing of corn, peanut, and beans, to be harvested in May/June. The second cycle begins in July/August producing a harvest in October/November. Different kinds of manioc can be sowed during the entire year. 
Agricultural production is basically for subsistence in the study area. The lower percentage of production destined exclusively for consumption in Santa María is because colonists there have other sources of food such as small livestock, while in Laguna-Raya people base their diet more on agricultural products. It is necessary to point out that when people indicate they produce for market this may only mean that part of their production is sold sporadically in local markets; in the case of Laguna-Raya, the market is the same community, while in Santa María, the markets are Chatarra or Villa Rica. Some authors (Padoch and de Jong, 1995, Bedoya, 1995, and Sierra, 1999) indicate that natives clear smaller areas than colonists because of less accessibility to the market, so they produce mainly for subsistence. In my studied communities, accessibility to the market is similar for both groups, this is a remote area far from markets and the costs of transportation are high, so in both communities people mainly produce for subsistence. In this case, as Sierra (1995) found, at any given time, natives and colonists resource use strategies respond to the relative value of alternative activities and situations.

Agricultural land size among comuneros in Laguna-Raya is smaller than in Santa María and there are significant differences with respect to agricultural land size between them (Table 13). In Santa Maria, colonists have more agricultural land because their properties are also bigger than the properties in Laguna-Raya. There are also significant differences between the distance from householder's house to his chacra in both communities. In Laguna-Raya this distance averages 48 minutes by foot, while in Santa María it averages 18 minutes. This difference is because most of the colonists have their chacras and houses on the same land, while most of the comuneros have their chacras far from the town, where they have their houses. 


\section{Agriculture in uplands}

The prevailing farming system in the uplands for both communities is based on slash and burn cultivation, incorporating basically subsistence crops. Comuneros from Laguna-Raya, because less riparian zones are available, use more area in uplands than colonist from Santa Maria, however no significant differences were found between the area used in uplands in both communities.

Also there are not significant differences in the period of rotation farmers leave in these two communities, and even when the time of rotation seems to be very short according to the literature, only $31.4 \%$ of people in Laguna-Raya and $33.3 \%$ in Santa Maria reported that production decreases with time.

In the study area the main crops sowed in uplands are manioc and plantain. Significant differences were found between the percentage of producers of these crops in both communities. More people in Laguna-Raya produce manioc than in Santa María. The reason is that manioc, by tradition, is the staple for natives in the Peruvian Amazon.

\section{Agriculture in riparian zones}

According to the Yanesha natives from Laguna-Raya, riparian zones or "cementeras" extend from the edges of rivers until the high mark of water; there is not a specific distance from the edge of the river, but they are inundated zones (approximately $100 \mathrm{~m}$ of width). For colonists in Santa María, riparian zones are beaches and the edges of rivers.

Richard Smith's impression is that traditionally the Yanesha did not use riparian zones very much. In 1967 when he first entered Loma Linda, he saw a lot of forest along 
the Palcazu river. For Smith the Yanesha settlement pattern was not to be close to rivers, it was to look for some hill and build his house there, and below it establish his chacra growing mainly manioc and corn. The Yanesha with easy access to rivers built temporary huts on beaches during the summer for fishing, and probably they grew some fastgrowing crops such as beans and peanuts (Personal communication, May 2001). However Bradley Bennett (Personal communication, November 2001) sais that traditionally natives in the Amazon use riparian zones, so further research respect to this needs to be done.

Today not all people in both communities have access to riparian zones. this does not mean necessarily that all these comuneros have riparian zones in their lands. There are communal riparian zones accessible to every comunero that ask for them, generally for people without access to them in their lands. In this case all colonists have had access to these areas since they settled in the community.

Comuneros in Laguna-Raya have an average length of river in their properties of 315 meters, this is because the first settlers in the community by general assembly decided that their properties should have 300 meters along lowlands (this mean along rivers). In Santa María, the average length was almost double that in Laguna-Raya, resulting in significant differences between these two communities. This difference is due to one person in Santa María who has 3000 meters of river front on his property. I considered 3000 as an outlier and dropped it. The new mean for Santa María was 489 meters and in this case there are not significant differences in length of river between these two communities. The length of river is important because it is a measure of 
riparian zone availability but topography is also important, and as we saw before in the ethnographic study, Laguna-Raya presents a flatter topography than Santa María.

In both communities a great percentage of people leave a fringe of trees as protection of their lands in riparian zones. Here again there was an outlier value in Laguna-Raya data, and excluding it the new mean of protection fringe is 19.32 meters. The people in Laguna-Raya leave a fringe of protection because of an internal agreement among the members of the community in a general assembly. Through social learning, comuneros understood the importance of leaving a fringe of protection which they agreed should be between 20 and 30 meters. According to law land owners with properties close to rivers must leave a fringe of trees in riparian zones as a way of protection; the title of property states that the owner must leave a $50 \mathrm{~m}$ wide trip, but some people in Santa Maria do not leave this width because in the last flood the river took part of their riparian zones (the river floods each 10 years, more or less $10 \mathrm{~m}$ ).

Most people in both communities have their protection fringe in riparian zones with vegetation and significant differences between both communities were found. The lower percentage of forest in the protection fringe in Santa María, even when their titles establish they should leave it forested, is because in 1996 there was a big flood and the Palcazu river removed the riparian vegetation of some properties.

Beyond the protection fringe in riparian zones, people in both communities establish their chacras. Riparian zones usually are much smaller areas physically as well, limiting the use to which they can be put. Although the Yanesha are traditionally said to not use riparian zones for agriculture, the Yanesha who settled Laguna-Raya apparently showed a preference for clearing lands in the riparian zone from the first settlement. 
Possibly the convertion to Adventism influenced some of their other cultural and agricultural practices.

Staver (1989) affirms that riparian zones are scarce and most Yanesha communities in the Palcazu valley have from 1 to 5 ha per family in riparian zones. These ranges are between the ones found in my study (Table 19). Significant differences exist in the area of riparian zone under use between these communities. The reason for larger areas used by colonists is that they have a greater length of river in their property and for that more availability of riparian zones than comuneros.

Comparing the percentages of crop producers in riparian zones between these communities, I found no significant differences among the majority of these crops, however significant differences were found in the percentages of producers of beans and peanuts between these communities. These differences are because Laguna-Raya riparian zones are flatter than Santa Maria riparian zones, and they are more appropriate for the cultivation of beans and peanuts which require sandy soils. In both places, people mostly produce in riparian zones for consumption. For the comuneros the most important agricultural production is in riparian zones because there people can sow subsistence crops, which are important sources of protein, vitamin and minerals, and provide variety in their diet. Also they are important crops for feeding poultry (such as corn).

According to Salick (1986) the distribution of crops in riparian zones in both communities, is because beans and peanut require the most fertile and fine soils, and they are sowed in riparian zones, close to the edge; corn and plantain are susceptible to aluminum toxicity, and sensitive to low $\mathrm{pH}$ the site is abandoned and flooding and are limited to low lands or rich places in uplands. Manioc is a tolerant crop with wide 
distribution, however because it is a root and easily damaged by water it is cultivated farther from the edge. Pituca requires good and well-drained soils. $\mathrm{Ph}$, aluminum, and nutrient compositions of riparian zones soils explain the concentration of crops that demand nutrient and are sensitive to $\mathrm{pH} / \mathrm{Al}$.

Stronger communal structure in the native community results in a greater respect of buffer zones and awareness of their ecological value. All the comuneros in LagunaRaya consider that riparian zones are important for protection of their lands and because of soil fertility. They said they learned this through experimentation, because their grandparents cut forest in riparian zones and they realized that because of this when the river rose it took part of their lands. Their parents and also professionals who where working in the place told them that it is a good practice to leave a fringe of forest as protection of their lands. For the colonists, most of them are aware of the importance of riparian zones because professionals told them and because by law it is established that they have to leave a fringe of 50 meters of forest, so formal education is not a factor that leads to conservation of riparian zones in these communities. 


\section{CONCLUSIONS}

The results presented in this study show how colonists and natives use riparian zones in two communitites of the Palcazu basin, where few quantitative data previously existed.

The following conclusions are drawn from my analysis:

- Existing studies from Peru and Ecuador suggest that land use between natives and colonists varies, either because of differences in larger contextual circumstances of the group or because of accessible markets. We may assume that differences in land use extend to riparian forests in these zones as well.

- Laguna-Raya and Santa Maria are socially mixed communities with a relatively young population. Although these communities are characterized by a mixed population, they are still characterized as native and colonist on the basis of land tenure.

- Household size is bigger in Laguna-Raya ( 5 members on average) than in Santa María ( 4 members on average), and comuneros in the native community have on average 4 children, while in Santa Maria, the householders have on average 3 children.

- Level of education is higher among the comuneros in the native community (LagunaRaya) where $33 \%$ of them have completed primary school, while in Sta. María only $24 \%$ completed primary school. In addition while the average of years of schooling completed in Santa María is 4, it is 6.7 in Laguna-Raya.

- Agriculture is the most important economic activity for people in Laguna-Raya and Santa María, and it is mainly for subsistence; however activities in Laguna-Raya are 
more diversified. Raising of small livestock is the second economic activity, and fishing is the third economic activity. Hunting and gathering are complementary activities.

- Average land holding in Laguna-Raya is 22.7 ha, while in Santa Maria it is 49.3 ha. Agricultural land size (land people can use for agriculture purposes) among comuneros in Laguna-Raya is on average 9.4 ha, and 17.3 ha on average among colonists in Santa María.

- In Laguna-Raya $80.4 \%$ of the farmers cultivate in uplands, and the land size under use averages 2.02 ha, while $76.2 \%$ do this in Santa María with an average land size of 1.49 ha. For comuneros from Laguna-Raya, agriculture is restricted by the lack of land in riparian zones and thus it depends on the use of more land in uplands.

- The general system of cultivation in uplands for both communities is that farmers cut an area, sow it and after an average of 1.5 years, they move to other area, having a rotation period of 3-4 years. Crops sowed in these areas include plantains, manioc, pituca, coffee, citrus, and others. However the main crops sowed there are manioc and plantains in both communities.

- Riparian zones are highly valued for agriculture by both native and colonist communities in the Palcazu basin. However in Laguna-Raya only $56.9 \%$ of the comuneros had access to them at the moment of the interview, and in Santa María $76.2 \%$ of colonists had access to riparian zones.

- Most of the people with access to riparian zones at their arrival to their respective community found these areas with abundant vegetation $(93.9 \%$ in Laguna-Raya and 
$87.5 \%$ in Santa Maria), and also most of them (78.8\% in Laguna-Raya and $68.7 \%$ in Santa María) left riparian vegetation for protection of their lands.

- Comuneros in Laguna-Raya have an average length of river on their properties of 315 meters. In Santa María, the average length was almost double (656 meters) than in Laguna-Raya, and significant differences were found between these two communities. This difference is due to one person in Santa Maria has $3000 \mathrm{~m}$ of river front on his property, so this extreme value was considered as an outlier and dropped, and no significant differences were found in the length of river between these communities.

- A great percentage of people, $87.9 \%$ in Laguna-Raya and $75 \%$ in Santa María, leave a fringe of trees as protection of their lands in riparian zones. The average of this fringe is 22.1 meters in Laguna-Raya and 27.5 meters in Santa María. The fact that people in Laguna-Raya leave a fringe of protection is because an internal agreement among the members of the community in a general assembly. However colonists in Santa Maria leave this fringe because the law establishes this in their titles.

- Comuneros in the native community use on average 1.1 ha of riparian zones, while colonist in Santa María use 1.85 ha. Riparian zones are sowed once per year, and the most frequent crops sowed in Laguna-Raya are corn, peanuts, beans, manioc, plantains, and pituca; but corn and plantains are the most grown. In Santa Maria typical crops grown in riparian zones are corn, manioc, and plantains.

- Riparian zones are highiy important areas for people in both communities for soil protection and soil fertility. Stronger communal structure in the native community result in a greater respect of buffer zone, and awareness of their ecological value, so 
in theses cases formal education was not a factor that leads with conservation of riparian zones.

- Statistic tests showed that riparian land use practices (including non-riparian land use) in both native and colonist communities in the Palcazu basin are similar. Contextual circumstances in both communities are similar and markets are distant. My research suggests that there is nothing inherent in the culture of either Yanesha peoples or colonists that leads them to open more or less agricultural land. 


\section{REFERENCES}

Albernaz, A. L. and M. Ayres. Selective logging along the middle Solimoes River. Várzea: diversity, development, and conservation of Amazonia's white water floodplains. The New York Botanical Garden Press. 407.

Anderson, A; I. Mousasticoshvily Jr.; D. Macedo. 1999. Logging of Virola surinamensis in the Amazon floodplain: impacts and alternatives. Várzea: diversity, development, and conservation of Amazonia's white water floodplains. The New York Botanical Garden Press. 407.

Bedoya, E. 1998. The social and Economic causes of deforestation in the Peruvian Amazon Basin: natives and colonists. The social causes of environmental destruction in Latin America. M. Painter \& W. H. Durham. Ann Arbor, University of Michigan, 217246pp.

Bjorkland, Ronald (Department of Geography), Shreves Charles Jr. (School of Environmental Design), Catherine Pringle (Institute of Ecology). 1997. Riparian environments: values, threats, management and restoration; an educational outreach slide show and text. University of Georgia, Athens, Georgia.

Blackwell, D., D.V. Hogan and E. Maltby. The use of conventionally and alternatively located buffer zones for the removal of nitrate from diffuse agricultural run-off. In: Wat. Sci. Tech. Vol 39, N¹2, pp. 157-164. 1999.

Boulan, R. 1999. El valle del Palcazu, análisis social y aspectos del desarrollo de la comunidad. Conservación de los bosques de la Amazonía alta en la selva central del Perú. Pronaturaleza.

Brack, A. 1997. Atlas de Comunidades Indígenas. Peru.

Bren, L,J. 1993. Riparian zone, stream, and floodplain issues: a review. Journal of Hidrology. $150: 277-299$.

Brodie, Chris; S, Wellman and A, Gough. The importance of riparian zones, and management implications. Paper presented at the Insight Conference "Recent Initiatives to streamline Forest Practices in B.C.". April 28-29, 1998; Four seasons Hotel, Vancouver.

Browder, J. 1995. Redemptive Communities: indigenous knowledge, colonist farming systems, and conservation of tropical forests. Agriculture and Human Values. Winter 1995: 17-30. 
Clawson, M. and C. L. Steward. 1965. Land use information: a critical survey of U.S. Statistics Including Possibilities for Greater Uniformity. The Johns Hopkind Press for Resources for the Future Inc. As cited by Prakash, J 1997.

Department of Natural Resources-Water and Land Resources Division. 5/12/00. The value of riparian vegetation. Splash.metrokc.gov/wlr/pi/ripveg.htm.

Enriquez, C. 2001. Diagnóstico de uso de la tierra de la comunidad nativa de Shiringamazú-Valle del Palcazú. PRONATURALEZA-Programa Selva Central Flanco Palcazú. 94pp.

GEF/PNUD/UNOPS. 1997. Amazonia peruana comunidades indígenas, conociminetos y tierras tituladas: Atlas y base de datos. Lima.

Gregory, Stanley. 1991. An ecosystem perspective of riparian zones focus on links between land and water. Bio Science. 41 (8).

Hartshorn, G. 1990. Natural Forets Management by the Yanesha Forestry Cooperative in Peruvian Amazonia. Alternatives to deforestation: steps toward sustainable use of the Amazon rainforest. Columbia University Press. New York. 128-138pp.

Hiraoka, M. 1986. Zonation of mestizo riverine farming systems in Northeast Peru. National Geographic Research. 2 (3): 354-371.

Hiraoka, M. 1989. Agricultural systems on the floodplains of the Peruvian Amazon. Fragile lands of Latin America, strategies for sustainable development. Westview Press. 75-101.

INEI. 1997. Compendio Estadístico Departamental 1996-97. Pasco. Lima. 212pp.

INEI, Ministerio de Agricultura. 1996. III Censo Nacional Agropecuario, Resultados definitivos. Departamento de Pasco. 18. Tomo I. Lima. 688pp.

INEI. 1994. Censo Nacional 1993, IX Poblacional y IV vivienda. Resultados definitivos a nivel provincial y distrital. 602pp.

INEI. 2001. Estimación de la población por grupos de edad según departamentos, provincias y distritos. Pasco.

JRB Associates. 1981. Central Selva, natural resources management project. USAID Project N527-0240. Vol I.

Lambou, V. W. 1989. Management Needs for Fishes and Fisheries Dependent on Overflow Riverine Wetlands. In Wetlands and River Corridor Management. Eds. J. A. 
Kusles and D. Daly Proc. Of an International Symposium, July 5-9 1989, Charleston, South Carolina, USA: 123-131.

Lillesand, T. M and W. Kiefer. 1987. Remote Sensing and Image Interpretation. John Wiley and Sons, New York. As cited by Prakash J. 1997.

Meggers, B. 1984. The indigenous peoples of Amazonia, their cultures, land use patterns and effects on the landscape and biota. The Amazon, limnology and landscape ecology of a mighty tropical river and its basin. Monographiae Biologicae. Vol 56: 226-237.

Naiman, Robert. 1988. The potential importance of boundaries to fluvial ecosystems.

Naiman R \& R, Bilby. 1998. River ecology and management, lessons from the Pacific Coastal Ecoregion. Springer-Verlag New York Inc. 705p.

Naiman, Robert \& Décamps, Henri. 1990. The ecology and management of aquaticterrestrial ecotones. Man and the Biosphere Series. Volume 4. UNESCO and The Parthenon Publishing Group.

Naiman, Robert; Décamps, Henri; Pollock, Michael. 1993. The role of riparian corridors in maintainig regional biodiversity. En: Ecological Applications. 3 (2) : 209-212.

Naiman, Robert \& Décamps, Henri. 1997. The ecology of interfaces-riparian zones.

Navone, S; E. Palacin; C. Movia; A. Maggi; E. Rienzi. 1998. Imágenes de radar, su utilización en la identificación de paisajes en la cuenca de Santa María (Catamarca, Argentina). Symposium: Radarsat applications in Latin America.

N/N. 1995. Plan integral desarrollo provincial 1995-2000. Huancabamba. Mayo.

Ordoñez, J. 2001. Análisis hidrometereológico y aplicación de un modelo de simulación en la cuenca del río Pachitea. Tesis. Universidad Nacional Agraria La Molina. Lima, Perú. 86p.

Ostrom, E; J. Burger; C. Field; R. Norgaard; D. Policansky. 1999. Revisiting the commons: local lessons, global challenges. Science. Vol 284. April. 278-282.

Ozorio, A. 1995. Sustainable Settlement in the Brazilian Amazon. Oxford University Press. New York.

Padoch, C. 1988. People of the floodplain and forest. People of the Tropical Rain Forest. University of California Press and Smithsonian Institution Traveling Exhibition Service.

Padoch, C and W. de Jong. 1995. Subsistence and market oriented agroforestry in the Peruvian Amazon. 226-237p. In T. Nishizawa and J. 
Uitto (eds.) The Fragile Tropics of Latin America: Changing Environments and their Sustainable Management. United Nations University Press: Tokyo.

Padoch, C; Ayres, J; Pinedo-Vasquez, M; Henderson, A. 1999. Várzea: diversity, development, and conservation of Amazonia's white water floodplains. The New York Botanical Garden Press. 407.

Pronaturaleza. 1999. Yanesha communities of the Palcazu valley socio-economic environment in the zones I and II. Report.

Raffles, H. 1999. Exploring the Anthropogenic Amazon: Estuarine landscape transformation in Amapá, Brazil. Várzea: diversity, development, and conservation of Amazonia's white water floodplains. 355-371

Rosales, J; C, Knab-Vispo y G, Rodríguez. 1997. Bosques riberenos del bajo Caura entre El Salto y los Raudales de la Mura: su clasificación e importancia en la cultura Ye'kwana. En: Scientia Guaianae. 7: 171-213.

Rudel, T; D. Bates; R. Machinguiash. 2000. Are ethnic differences in land use enduring?: Land use changes among Shuar and Colonist Smallholders in the Ecuadorian Amazon. LASA Conference 2000, Miami, Florida, March.

Salick, J. 1986. Etnobotanica de los Amuesha, Valle Palcazu, Peru.

Santos Granero, F \& F, Barclay. 1998. Selva Central, History, Economy, and Land Use in Peruvian Amazonia. Smithsonian Institution Press. Washington and London. 351p.

Schiemer, F \& Zalewski, M. 1992. The importance of riparian ecotones for diversity and productivity of riverine fish communities. Netherlands Journal of Zoology. 42 (2-3): 323335.

Schjellerup, J. 2000. La Morada, a case study on the impact of human pressure on the environment in the Ceja de Selva, Northeastern Peru. Ambio. 29 (7): 451-454.

Sierra, R. 1999. Traditional resource-use systems and tropical deforestation in a multiethnic region in North-west Ecuador. Environmental Conservation. 26 (2): 136-145.

Smith, N. 1999. Biodiversity and agroforestry along the Amazon floodplain. Traditional and modern natural resource management in Latin America.University of Pittsburgh Press. 233-250.

Smith, R. 1982. The dialects of domination in Peru: native communities and the myth of the vast Amazonian emptiness. Cultural Survival Institute. 131p. 
Staver, C. 1989. Why farmers rotate fields in maize-cassava-plantain bush fallow agriculture in the wet Peruvian Amazon. Human Ecology. 17 (4): 401-426.

Svejcar, T. 1997. Riparian zones: What are they and how do they work?. Rangelands 19 (4). $4-7 \mathrm{pp}$.

Svejcar, T. 1997. Riparian zones: history and human impacts. Rangelands 19 (4). 8-12pp.

Welsch, David. 1991. Riparian forest buffers, function and design for protection and enhancement of water resource. 


\section{Appendix 1}

Riparian Fields (Laguna-Raya):

\begin{tabular}{|c|c|c|c|c|c|}
\hline Name & East & North & $\begin{array}{c}\text { Parcel } \\
\text { Area with } \\
\text { crops (m2) }\end{array}$ & $\begin{array}{l}\text { Edge of } \\
\text { protect } \\
\text { (m) }\end{array}$ & Crops \\
\hline \multicolumn{6}{|l|}{ Puerto Laguna } \\
\hline Colegio & $18489309 \mathrm{E}$ & $8856695 \mathrm{~N}$ & $70 \times 30$ & 10 & Plantain, pasture (maicillo) \\
\hline Jaime Chihuanco & $18489276 \mathrm{E}$ & $8856759 \mathrm{~N}$ & $50 \times 40$ & 17 & Plantain, pituca \\
\hline Mario o Elizandro & $18489232 \mathrm{E}$ & $8856839 \mathrm{~N}$ & $50 \times 40$ & 50 & Plantain, manioc, pituca \\
\hline Alván Coñibo & $18489229 \mathrm{E}$ & $8856999 \mathrm{~N}$ & $95 \times 30$ & 5 & Plantain, pituca \\
\hline Anselmo Cruz & $18489968 \mathrm{E}$ & $8857122 \mathrm{~N}$ & $30 \times 30$ & 20 & Manioc, plantain \\
\hline Segundo Valerio & $18490355 \mathrm{E}$ & $8857400 \mathrm{~N}$ & $25 \times 15$ & 5 & Peanut, com \\
\hline Remigio Valerio & $18490272 \mathrm{E}$ & $8857421 \mathrm{~N}$ & $50 \times 50$ & 50 & Corn, plantain \\
\hline Adan Vallestero & $18490204 \mathrm{E}$ & $8857463 \mathrm{~N}$ & $50 \times 50$ & 50 & corn \\
\hline Tito Misei & $18490231 \mathrm{E}$ & $8857589 \mathrm{~N}$ & $20 \times 20$ & 10 & Manioc, plantain \\
\hline Colegio & $18489891 \mathrm{E}$ & $8857709 \mathrm{~N}$ & $200 \times 200$ & 5 & Pasture \\
\hline $\begin{array}{l}\text { Empresa Ganadera } \\
\text { Forestal Puerto } \\
\text { Laguna }\end{array}$ & $18489540 \mathrm{E}$ & $8857705 \mathrm{~N}$ & $2 \times 130$ & 10 & Pasture \\
\hline Mauro Coñibo & $18487855 \mathrm{E}$ & $8857519 \mathrm{~N}$ & $80 \times 90$ & 10 & Pasture, plantain \\
\hline \multicolumn{6}{|l|}{$\begin{array}{l}\text { Raya } \\
\text { Right marg }\end{array}$} \\
\hline César López & $18488720 \mathrm{E}$ & $8856332 \mathrm{~N}$ & $50 \times 50$ & 2 & Manioc, plantain, pituca \\
\hline \multicolumn{6}{|l|}{ Anselmo Cruz } \\
\hline Elí López & $18487918 \mathrm{E}$ & 8855741 & $100 \times 100$ & 25 & Plantain, corn, pituca, manioc \\
\hline Pedro Joaquín & 18487440 & 8855877 & $25 \times 25$ & 15 & Peanut, plantain, corn, pituca \\
\hline $\begin{array}{l}\text { Pablo Potestá } \\
\text { Santos }\end{array}$ & $18487920 \mathrm{E}$ & $8854993 \mathrm{~N}$ & $250 \times 150$ & 50 & Pasture, tocné \\
\hline Mariano Antazú & $18488017 \mathrm{E}$ & $8853962 \mathrm{~N}$ & & & Manioc, plantain, pituca \\
\hline Francisco Miguel & $18487612 \mathrm{E}$ & $8853927 \mathrm{~N}$ & $150 \times 25$ & 13.5 & Manioc, pituca, corn \\
\hline Gerónimo Valerio & $18486780 \mathrm{E}$ & $8853823 \mathrm{~N}$ & $15 \times 10$ & 50 & Pasture \\
\hline $\begin{array}{l}\text { Manuel Sinchi } \\
\text { (Taxi) }\end{array}$ & $18485907 \mathrm{E}$ & 8853538 & $100 \times 100$ & 10 & Manioc, plantain, pituca \\
\hline $\begin{array}{l}\text { Left marg } \\
\text { Miguel Huayoli }\end{array}$ & PURMA & & & & \\
\hline Colegio & $18488905 \mathrm{E}$ & $8856438 \mathrm{~N}$ & $50 \times 50$ & 20 & Corn, plantain, beans \\
\hline Juan Torres 1 & $18488300 \mathrm{E}$ & $8855981 \mathrm{~N}$ & $50 \times 50$ & 25 & corn \\
\hline Juan Torres 2 & $18488360 \mathrm{E}$ & $8856036 \mathrm{~N}$ & $25 \times 25$ & 5 & manioc \\
\hline Jorge Casimiro & $18488264 \mathrm{E}$ & $8855904 \mathrm{~N}$ & $20 \times 25$ & 11.5 & Manioc, plantain \\
\hline Aurelio López & $18487721 \mathrm{E}$ & $8855726 \mathrm{~N}$ & $200 \times 70$ & 10 & $\begin{array}{l}\text { Plantain, manioc, pijuayo, } \\
\text { pituca }\end{array}$ \\
\hline Nemesio Mesa & $18487768 \mathrm{E}$ & $8856016 \mathrm{~N}$ & $50 \times 50$ & 17 & Manioc, plantain, pasture \\
\hline Pedro Francisco & $18488204 \mathrm{E}$ & $8854815 \mathrm{~N}$ & $200 \times 100$ & 7 & Manioc, plantain, corn \\
\hline
\end{tabular}




\begin{tabular}{|l|l|l|l|l|l|}
\hline Raúl Valerio & $18487866 \mathrm{E}$ & $8853904 \mathrm{~N}$ & $150 \times 40$ & 7 & Manioc, plantain \\
\hline Héctor Mariño & $18487118 \mathrm{E}$ & $8853934 \mathrm{~N}$ & $100 \times 100$ & 7 & Pasture, tornillo \\
\hline Segundo Valerio & $18486769 \mathrm{E}$ & $8853646 \mathrm{~N}$ & $300 \times 200$ & 5 & Pasture \\
\hline
\end{tabular}

\begin{tabular}{|l|l|l|l|}
\hline \multicolumn{1}{|c|}{ Name } & \multicolumn{1}{c|}{ East } & \multicolumn{1}{c|}{ North } & \multicolumn{1}{c|}{ Altitude (M) } \\
\hline Puente Raya & $18489327 \mathrm{E}$ & $8856351 \mathrm{~N}$ & 307 \\
\hline Intersection Raya-Corvina rivers & $18486838 \mathrm{E}$ & $8853783 \mathrm{~N}$ & 441 \\
\hline Intersection Raya-Palcazu rivers & $18490420 \mathrm{E}$ & $8857034 \mathrm{~N}$ & 337 \\
\hline Puente Carachama & $18487884 \mathrm{E}$ & $8857572 \mathrm{~N}$ & 348 \\
\hline Ito community & $18488127 \mathrm{E}$ & $8857674 \mathrm{~N}$ & 341 \\
\hline
\end{tabular}

\section{Riparian Fields (Santa Maria):}

\begin{tabular}{|l|l|l|l|l|l|}
\hline \multicolumn{1}{|c|}{ Name } & \multicolumn{1}{|c|}{ East } & \multicolumn{1}{|c|}{ North } & \multicolumn{1}{|c|}{$\begin{array}{c}\text { Parcel } \\
\text { Area with } \\
\text { crops (m) })\end{array}$} & $\begin{array}{c}\text { Edge of } \\
\text { protect } \\
\text { (m) }\end{array}$ & Crops \\
\hline Yolanda Cruz 1 & $18493901 \mathrm{E}$ & $8851386 \mathrm{~N}$ & $50 \times 50$ & 3 & corn, manioc, peanut \\
\hline Yolanda Cruz 2 & $18494131 \mathrm{E}$ & $8851171 \mathrm{~N}$ & $50 \times 50$ & 4 & manioc, plantain \\
\hline Fidel Fajardo & $18494411 \mathrm{E}$ & $8851132 \mathrm{~N}$ & $80 \times 50$ & 30 & plantain, achiote \\
\hline Maribel Sebastian & $18494285 \mathrm{E}$ & $8851322 \mathrm{~N}$ & $50 \times 50$ & 30 & pituca, plantain, citrus \\
\hline Mirko Novichevich & $18493744 \mathrm{E}$ & $8850197 \mathrm{~N}$ & $100 \times 100$ & 15 & plantain, corn \\
\hline Jose Aliong & $18495175 \mathrm{E}$ & $8846935 \mathrm{~N}$ & $100 \times 100$ & 10 & plantain, citrus \\
\hline Sosimo Mesa & $18495183 \mathrm{E}$ & $8848291 \mathrm{~N}$ & $100 \times 100$ & 50 & plantain, pijuayo \\
\hline Loayza & $18494520 \mathrm{E}$ & $8848543 \mathrm{~N}$ & $50 \times 50$ & 7 & corn, pituca, plantain \\
\hline Hedinger & $18494303 \mathrm{E}$ & $8848775 \mathrm{~N}$ & $100 \times 100$ & 15 & plantain, coconut, pijuayo \\
\hline Ernesto Ignacio & $18493465 \mathrm{E}$ & $8853268 \mathrm{~N}$ & $50 \times 50$ & 3 & corn, pituca \\
\hline Floriano & $18494734 \mathrm{E}$ & 8849570 & $100 \times 100$ & 10 & pasture, coffee \\
\hline
\end{tabular}


Appendix 2

Interview

- Date

- \# of interview:

- Location:

- District:

- Province:

- Type of population:
a) Colonist
b) Native

- River's name:

- River's width:

- Total population in the community:

- \# of families in the community: 
1.1 Name:
1.2 Are you colonist?
a) Yes
b) No

If not, go to 1.2.2

1.2.1 If Yes, where are you from?
a) Highlands
b) Jungle
c) Coast
d) Austrian-German descendents
e) Other

1.2.2 Are you native?
a) Yanesha (Amuesha)
b) Ashaninka (Campa)
c) Pano (Cashibo, Shipibo, Conibo)

\subsection{Land tenure}

1.3.1 Land tenure type
a) Individual land
b) Communal land
c) Both

1.3.2 Land property

a) It is my property

b) I just work this land

c) I rent this land

1.3.3 How many years are you living here? years

1.3.4 Land legal status:

a) With title

- When did you receive it?

b) Did you request the title?

- When did you request it?

c) Without title

1.3.5 What is the size of your land? $\mathrm{Ha}$

\section{Family members}

2.1 Household size:

2.2 Details of family members:

\begin{tabular}{|c|c|c|c|c|c|c|}
\hline $\begin{array}{l}2.2 .1 \text { Relation with } \\
\text { the householder } \\
\text { head }\end{array}$ & $\begin{array}{l}2.2 .2 \\
\text { Sex }\end{array}$ & 2.2.3 Age & $\begin{array}{l}\text { 2.2.4 Level of } \\
\text { education }\end{array}$ & $\begin{array}{l}2.2 .5 \text { Where } \\
\text { are they?* }\end{array}$ & $\begin{array}{l}2.2 .6 \text { Main } \\
\text { activity }\end{array}$ & $\begin{array}{l}2.2 .7 \text { Time } \\
\text { spend in the } \\
\text { activity }\end{array}$ \\
\hline $\begin{array}{l}\text { * Members who } \\
\text { live at home } \\
1 \\
2 \\
3 \\
4 \\
5 \\
* \text { members who } \\
\text { live in other place } \\
1 \\
2 \\
3\end{array}$ & & & & & & \\
\hline
\end{tabular}


- Reason why these members left home?
a) Studies
b) Job
c) Other reason

\section{RIPARIAN ZONES}

3.1 How much of your land is riparian zones?

Width $\left(\mathrm{m}^{2}\right)$

Length of river

3.2 If not, why do you not have access to riparian zones?

3.3 What proportion of their riparian zones are forested?

$(\%)$

3.4 How did you find riparian zones in your property at your arrival?
a) This has abundant forest
b) There were nothing of forest
c) There was vegetation in some parts
d) Other

3.5 What did you do with the riparian vegetation?
a) I cut part of it to establish my chacra
b) I left it as a protection of my land
c) Other people cut it because of the wood (forestry concessions)
d) I cut it for better visibility
e) Other

3.6 Do you use riparian zones for some activity?
a) Yes
b) No

3.7 What activity do you do in riparian zones?

a) Agriculture

b) Cattle ranching

c) Fishing

d) Gathering

e) Hunting

f) Nothing

\begin{tabular}{|l|l|l|l|l|}
\hline Activity & $\begin{array}{l}\text { Time spend in the } \\
\text { activity } \\
\text { (days/week) }\end{array}$ & $\begin{array}{l}\text { Total production } \\
\text { last year }\end{array}$ & $\begin{array}{l}\text { Market sell last } \\
\text { year }\end{array}$ & $\begin{array}{l}\text { Consumption last } \\
\text { year }\end{array}$ \\
\hline 1. Agriculture & & & & \\
$-\begin{array}{l}\text { Corn } \\
\text { Beans }\end{array}$ & & & & \\
$-\begin{array}{l}\text { Peanuts } \\
\text { Manioc } \\
\text { Plantains } \\
\text { Pituca } \\
\text { Rice } \\
\text { Watermelon } \\
\text { Others }\end{array}$ & & & & \\
\hline
\end{tabular}




\begin{tabular}{|l|l|l|l|l|}
\hline 2. Cattle ranching & & & & \\
- Cow & & & & \\
\hline 3. Fishing & Carachama & & & \\
$-\quad$ Boquichico & & & & \\
$-\quad$ Chupadora & & & & \\
$-\quad$ Others & & & & \\
\hline 4. Hunting & Majaz & & & \\
$-\quad$ Cutpe & & & & \\
$-\quad$ Sajino & & & & \\
$-\quad$ Pucacunga & & & & \\
\hline
\end{tabular}

3.8 Why did you choose riparian zones to cultivate these crops instead uplands?
a) These crops growth better there
b) Because of soil fertility d) Others

3.9 If not, why do you not use riparian zones?

a) Because this place is for protection

b) Because there I cannot cultivate the crops I want

c) Because of annual floods

3.10 Have you reforested riparian zones?
a) Yes
b) No

3.10.1 If Yes, what species have you planted?

\begin{tabular}{|l|l|l|}
\hline Specie name & Reforestation area & Purpose of species election* \\
\hline 1. Native species & & \\
a) & & \\
b) & & \\
d) & & \\
e) Exotic species & & \\
$2 . \quad$ & & \\
a) & & \\
b) & & \\
c) & & \\
\hline e) & & \\
\hline
\end{tabular}

*1) I was advised to plant these

2) Because of wood

3) Because the Agriculture Ministery gave us these

3.11 Are you familiar with the ecological importance of riparian zones?
a) Yes
b) No

3.11.1 Is Yes, why is it important?

a) Protection of my land

b) To avoid erosion 
c) Existence of more flora and fauna

d) This area proportionate water

e) To avoid water contamination

f) Soil quality (soil fertility)

\section{ECONOMIC ACTIVITIES}

4.1 What are the 3 more important activities in terms of subsistence or consumption?
a) Agriculture
b) Cattle ranching
c) Raising
d) Hunting
e) Fishing
f) Gathering
g) Guide
h) Matero
i) Taxi driver
j) Boat driver
k) Employee
1) Other

4.2 What are the 3 more important activities in terms of income?
a) Agriculture
b) Cattle ranching
c) Raising
d) Hunting
e) Fishing
f) Gathering
g) Guide
h) Matero
i) Taxi driver
k) Boat driver
k) Employee
1) Other

4.3 How far is the market from your home? $\mathrm{km}$ (minutes)

4.3.1 How do you go to the market?
a) By walking
b) By road

\subsection{Agriculture:}

4.4.1 Purpose of the activity:

a) Exclusively for consumption b) Exclusively for market

c) Both

4.4.2 How far is your chacra from your home? $\mathrm{Km}$ or $\mathrm{Hr}$

4.4.3 Total agricultural land $\mathrm{Ha}($ or $\%)$

4.4.4 How many years have you had your actual chacra in the same place?

4.4.5 How many years can you plant in the same place?

4.4.6 How long is your rotation period?

4.4.7 Is enough the Ha/year to keep your family?

4.4.8 How many $\mathrm{Ha} /$ year do you need to keep your family?

4.4.9 Is manioc production per year enough to cover the needs of your family?
a) Yes
b) No

4.4.10 Agricultural production and consumption 


\begin{tabular}{|l|l|l|l|l|}
\hline Crop & $\begin{array}{l}\text { Time spend to } \\
\text { the activity } \\
\text { Days/week }\end{array}$ & $\begin{array}{l}\text { Total production last } \\
\text { year (Ha or \%) }\end{array}$ & $\begin{array}{l}\text { Market sells } \\
\text { last year }(\mathrm{Kg} \\
\text { or \%) }\end{array}$ & $\begin{array}{l}\text { Consumption } \\
\text { last year }(\mathrm{Kg} \\
\text { or \%) }\end{array}$ \\
\hline 1. Plantains & & & & \\
2. Manioc & & & \\
3. Rice & & & \\
4. Coffee & & & \\
5. Corn & & & \\
6. Beans & & & \\
8. Pitrus & & & & \\
9. Others & & & \\
\hline Total & & & \\
\hline
\end{tabular}

4.5.12 What pest or diseases are affecting your crops?

\begin{tabular}{|c|c|c|c|c|c|c|c|c|c|}
\hline \multirow{2}{*}{$\begin{array}{l}\text { Pest or disease in } \\
\text { important commercial } \\
\text { crops }\end{array}$} & \multicolumn{3}{|c|}{$\begin{array}{l}\text { Control (insecticide, } \\
\text { herbicide, fertilizer) }\end{array}$} & \multicolumn{3}{|c|}{$\begin{array}{l}\text { Control frequency } \\
\text { (times/year) }\end{array}$} & \multicolumn{3}{|c|}{$\begin{array}{l}\text { Control quantity } \\
\text { (teaspoon/15 liters }\end{array}$} \\
\hline & Ins & Her & Fert & Ins & Her & Fert & Ins & Her & Fert \\
\hline $\begin{array}{l}1 . \\
2 . \\
3 . \\
4 . \\
5 .\end{array}$ & & & & & & & & & \\
\hline
\end{tabular}

\subsubsection{Factors affecting crop production}

4.5.13.1 Has the production diminished with time?
a) Yes
b) No

4.5.13.2 If Yes, What do you think is the reason?
a) Lack of fertility
b) Over population
c) Pests
d) Use of insecticides or other chemicals
e) Introduction of exotic species
f) No idea

\subsection{Cattle raising:}

4.6.1 Purpose of the activity:
a) Exclusively for consumption b) Exclusively for market
c) Both

4.6.2 How do you manage your cattle?
a) I saw pasture (intensive)
b) I leave he cattle free (extensive) 
4.6.3 Type of cattle

\begin{tabular}{|c|c|c|c|c|c|c|c|}
\hline \multirow[t]{2}{*}{ Type of cattle } & \multirow{2}{*}{$\begin{array}{l}\text { Number } \\
\text { of animals } \\
\text { (Unit) }\end{array}$} & \multirow{2}{*}{$\begin{array}{l}\text { Land } \\
\text { used for } \\
\text { pasture } \\
\text { (ha) } \\
\end{array}$} & \multirow{2}{*}{$\begin{array}{l}\text { Time spend in } \\
\text { the activity } \\
\text { Days/week }\end{array}$} & \multicolumn{2}{|c|}{$\begin{array}{l}\text { Market sells last } \\
\text { year }\end{array}$} & \multicolumn{2}{|c|}{$\begin{array}{l}\text { Consumption last } \\
\text { year }\end{array}$} \\
\hline & & & & $\begin{array}{l}\text { Meat } \\
\text { (unit) }\end{array}$ & $\begin{array}{l}\text { Milk } \\
\text { (liter) }\end{array}$ & $\begin{array}{l}\text { Meat } \\
\text { (unit) }\end{array}$ & $\begin{array}{l}\text { Milk } \\
\text { (liter) }\end{array}$ \\
\hline $\begin{array}{ll}\text { 1. } & \text { Cow } \\
\text { 2. } & \text { Cebú } \\
\text { 3. } & \text { Sheep } \\
\end{array}$ & & & & & & & \\
\hline Total & & & & & & & \\
\hline
\end{tabular}

4.6.4 What diseases or parasites are affecting your cattle?

\begin{tabular}{|l|l|l|l|}
\hline Disease or parasite & $\begin{array}{l}\text { Control (insecticide } \\
\text { name) }\end{array}$ & $\begin{array}{l}\text { Control frequency } \\
\text { (times/year) }\end{array}$ & $\begin{array}{l}\text { Control quantity used } \\
\text { per animal }\end{array}$ \\
\hline 1. & & & \\
2. & & & \\
3. & & & \\
\hline
\end{tabular}

\subsection{Raising:}

4.7.1 Purpose of the activity:

a) Exclusively for consumptionb) Exclusively for market

c) Both

4.7.2 Type of livestock

\begin{tabular}{|l|l|l|l|}
\hline Livestock & $\begin{array}{l}\text { Number of } \\
\text { animals } \\
\text { (Unit) }\end{array}$ & $\begin{array}{l}\text { Market sells last } \\
\text { year (Unit) }\end{array}$ & $\begin{array}{l}\text { Consumption last } \\
\text { year (Unit) }\end{array}$ \\
\hline 1. Chicken & & & \\
2. Duck & & & \\
3. Turkey & & & \\
4. Cuy & & & \\
5. Pig & & & \\
\hline Total & & & \\
\hline
\end{tabular}

\subsection{Hunting:}

4.8.1 Purpose of the activity:

a) Exclusively for consumption b) Exclusively for market

c) Both 
4.8.2 Hunted animals

\begin{tabular}{|l|l|l|l|l|l|}
\hline Animals & $\begin{array}{l}\text { Number of } \\
\text { hunted } \\
\text { animals in } \\
\text { the last year }\end{array}$ & $\begin{array}{l}\text { Hunting } \\
\text { place* }\end{array}$ & $\begin{array}{l}\text { Time spend in } \\
\text { the activity } \\
\text { Days/week }\end{array}$ & $\begin{array}{l}\text { Market sells } \\
\text { last year (Unit) }\end{array}$ & $\begin{array}{l}\text { Consumption } \\
\text { last year } \\
\text { (Unit) }\end{array}$ \\
\hline 1. Sajino & & & & & \\
2. Majaz & & & & \\
3. Venado & & & & \\
5. Cutpe o anuje & Armadillo \\
6. Paujil & & & & & \\
7. Perdiz & & & & \\
8. Pucacunga & & & & & \\
9. Pava & & & & \\
10. Otros & & & & & \\
\hline Total & & & & & \\
\hline
\end{tabular}
*
a) Primary forest b) Secondary forest
c) Creeks
d) Chacra

4.8.3 In what period of the year do you hunt more animals?
a) Summer
b) Winter
c) All the year

\subsection{Fishing}

4.9.1 Purpose of the activity:

a) Exclusively for consumptionb) Exclusively for market

c) Both

\subsubsection{Quantity and purpose of fishing}

\begin{tabular}{|l|l|l|l|l|}
\hline $\begin{array}{l}\text { Quantity of } \\
\text { captured fish } \\
\text { (kg/capture) }\end{array}$ & $\begin{array}{l}\text { *Fishing } \\
\text { place }\end{array}$ & $\begin{array}{l}\text { Time spend in } \\
\text { the activity } \\
\text { days/week }\end{array}$ & $\begin{array}{l}\text { Market sells } \\
\text { last year (Unit } \\
\text { or } \mathrm{Kg} \text { ) }\end{array}$ & $\begin{array}{l}\text { Consumptio } \\
\text { n last year } \\
\text { (Unit or Kg) }\end{array}$ \\
\hline & & & & \\
\hline
\end{tabular}
a) Out from my property
b) Inside my property

4.9.3 Fishing methods:
a) With cane and hooks (anzuelo)
c) With arrow
b) With net (tarrafa)
c) By hand
4.9.4 Do you use poisons?
a) Yes
b) No

4,9.4.1 If Yes, What kind of poison do you use?
a) Natural:
i) Barbasco (cuve)
b) Chemical:
i) Powder
ii) Huaco
ii) Other
iii) Corteza de nogal

\subsection{Gathering}

4.10.1 Purpose of the activity:

a) Exclusively for consumption b) Exclusively for market

c) Both 
4.10.2 Quantity and purpose of gathering

\begin{tabular}{|l|l|l|l|l|l|}
\hline Type of products & $\begin{array}{l}\text { Quantity of } \\
\text { gathered } \\
\text { products } \\
\text { (kg/time) }\end{array}$ & $\begin{array}{l}\text { *Gatheri } \\
\text { ng place }\end{array}$ & $\begin{array}{l}\text { Time spend } \\
\text { in the } \\
\text { activity } \\
\text { days/week }\end{array}$ & $\begin{array}{l}\text { Market sells } \\
\text { last year (Unit) }\end{array}$ & $\begin{array}{l}\text { Consumption } \\
\text { last year } \\
\text { (Unit) }\end{array}$ \\
\hline $\begin{array}{l}\text { 1. Wood } \\
\text { 2. Fruits } \\
\text { 3. Medicinal plants } \\
\text { 4. Other }\end{array}$ & & & & & \\
\hline Total & & & & & \\
\hline
\end{tabular}
*
a) Primary forest b) Secondary forest
c) Creek d) Chacra

\subsection{Activities in service sector}

4.11.1 Type and purpose of service activities

\begin{tabular}{|l|l|l|l|}
\hline Type of activity & Work place & Number days/week & Income/month \\
\hline $\begin{array}{l}\text { 1. Employee } \\
\text { 2. Teacher } \\
\text { 3. Conductor } \\
\text { 4. Guide } \\
\text { 5. Other }\end{array}$ & & & \\
\hline
\end{tabular}

\section{Rivers/streams}

5.1 Are there rivers in your property?
a) Yes
b) No

\subsubsection{If Yes, how many?}

5.2 What is the length of the main river? meters

5.3 Is your land flooded annually?
a) Yes
b) No

5.4 How is the flood?

5.5 Are there other water sources in your property?
a) Yes
b) No

5.1.1 If Yes, how many? (Observations)

6. Make a drawing of your plot in riparian zones and distribution of your crops 